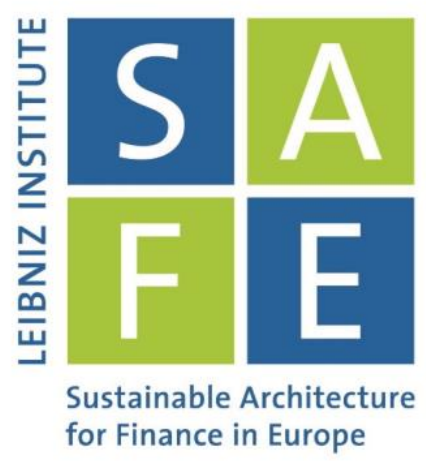

Christian Mücke | Loriana Pelizzon | Vincenzo Pezone | Anjan Thakor

\title{
The Carrot and the Stick: Bank Bailouts and the Disciplining Role of Board Appointments
}

SAFE Working Paper No. 316

\section{Leibniz Institute for Financial Research SAFE}

Sustainable Architecture for Finance in Europe 


\title{
The Carrot and the Stick: Bank Bailouts and the Disciplining Role of Board Appointments*
}

\author{
Christian Mücke ${ }^{\dagger}$, Loriana Pelizzon ${ }^{\ddagger}$, Vincenzo Pezone ${ }^{\S}$, and Anjan Thakor $\mathbb{I}^{\Perp}$
}

Tuesday $6^{\text {th }}$ July, 2021

\begin{abstract}
We empirically examine the Capital Purchase Program (CPP) used by the US government to bail out distressed banks with equity infusions during the Great Recession. We find strong evidence that a feature of the CPP - the government's ability to appoint independent directors on the board of an assisted bank that missed six dividend payments to the Treasury - helped attenuate bailout-related moral hazard. Banks were averse to these appointments - the empirical distribution of missed payments exhibits a sharp discontinuity at five. Director appointments by the Treasury led to improved bank performance, lower CEO pay, and higher stock market valuations.
\end{abstract}

\section{JEL Codes: G01, G2, G28, G38, H81 \\ Keywords: Bank Bailout, TARP, Capital Purchase Program, Dividend Pay- ments, Board Appointments, Bank Recapitalization}

\footnotetext{
*We thank Viral V. Acharya, Allen N. Berger, Arnoud Boot, Stefano Colonnello, Martin Götz, Radhakrishnan Gopalan, Robin Greenwood, Peter Haslag, Sheng Huang, Lars Norden, Marco Pagano, Cecilia Parlatore, Raghavendra Rau, Raluca Roman, Antoinette Schoar, Kandarp Srinivasan, Jeremy Stein, Richard Thakor, Edison $\mathrm{Yu}$, and seminar participants at the Washington St. Louis Finance Brown Bag Seminar, the SAFE Brown Bag Seminar (Goethe University, Frankfurt), Tilburg University, the Finance Forum, and the MoFiR Workshop on Banking for their helpful comments and suggestions. We gratefully acknowledge research support from the Leibniz Institute for Financial Research SAFE. We alone are responsible for remaining errors.

${ }^{\dagger}$ Goethe University Frankfurt - GSEFM and Leibniz Institute for Financial Research SAFE e.V. (muecke@safe-frankfurt.de)

${ }^{\ddagger}$ Leibniz Institute for Financial Research SAFE e.V., Goethe University Frankfurt, Ca’ Foscari University of Venice, and CEPR (Pelizzon@safe-frankfurt.de)

§Leibniz Institute for Financial Research SAFE e.V. (pezone@safe-frankfurt.de)

IWashington University in St. Louis, ECGI, FTG Fellow, and MIT LFE research affiliate (thakor@wustl.edu)

$\|$ Corresponding author
} 


\section{Introduction}

Despite the well-publicized negative effect of bailouts on ex ante incentives, it is often practically infeasible for governments to avoid bailing out failing banks, especially if many banks fail together, i.e., in the presence of systemic risk. This is the "too many to fail" phenomenon that has been noted in previous research (e.g., Acharya and Yorulmazer (2007), and Farhi and Tirole (2012)). We last witnessed this in spectacular fashion during the 200709 financial crisis, as governments all over the world scrambled to save scores of troubled institutions in order to prevent a cratering of their economies. Once governments realized that this was an insolvency risk crisis triggered by sharp declines in bank equity, the optimal course of action was deemed to be a rapid recapitalization of banks (e.g., Berger and Roman (2020), Greenwood, Hanson, Stein and Sunderam (2017), Thakor (2018a,b)) to harvest the private and social benefits of higher bank capital (e.g., Berger and Bouwman (2013)). But private recapitalization by banks is daunting because raising equity in the midst of a crisis may be difficult and expensive, so the government may provide the necessary capital by buying equity in troubled banks. However, as Philippon and Skreta (2012) and Tirole (2012) point out, this inevitably involves taxpayer subsidies for banks, so it has a direct cost. Moreover, there is also an indirect cost - such bailouts engender moral hazard (e.g., see Duchin and Sosyura (2014) for evidence), so the government has another reason to hold back on such financing ${ }^{1}$.

How should a government assist a distressed bank through a capital infusion, while also dealing with both the adverse ex ante effect on bank incentives ${ }^{2}$ as well as the possible adverse ex post incentives after receiving the capital infusion ${ }^{3}$ ?

In this paper, we investigate this issue by studying how the Federal Reserve and the U.S.

1. In particular, if banks anticipate that during times of distress they will receive subsidized equity from the government, then their incentives to be highly capitalized could potentially be weakened in the first place, which then makes it more likely that the government will have to step in and provide subsidized equity in the future.

2. Merton (1977) was the first to recognize that a de jure safety net like deposit insurance will generate risk-shifting incentives in banks and also encourage banks to use too little capital. A bailout, if anticipated, is a de facto safety net.

3. This incentive may be to run the bank in a way that does not protect the interests of the government, i.e., not to make dividend payments on the preferred stock purchased by the government. Indeed, the infusion of preferred stock may also create risk-shifting moral hazard (e.g. Acharya, Gujral, Kulkarni and Shin (2011)). 
Treasury addressed this question in designing the Capital Purchase Program (CPP) that was used to infuse equity capital into banks under the funding authorization provided by the Troubled Asset Relief Program (TARP). Under this program, started in October 2008, funding was provided by the U.S. Treasury to 707 banks using dividend-paying preferred shares and subordinated debt. A key feature of the program was the linking of quarterly payments on the securities owned by the Treasury to the say the government had in the corporate governance of the bank.

If the bank missed six quarterly dividend payments on the securities held by the Treasury, then it gave the Treasury the option to appoint up to two (voting) directors on the bank's board $^{4}$. It is clear that putting its own directors on the board allows the government to potentially exercise corporate governance influence to deal with ex post moral hazard. But whether the potential is realized to make this an effective mechanism depends on whether these are ceremonial appointments or involve directors with sufficient knowledge and experience to flex their corporate governance muscles and actually affect decision-making and bank performance. Moreover, the ex ante incentive effects are unclear. For example, if banks welcome the subsidized funding during a future crisis and view the government directors as ceremonial appointments, they may choose to be very thinly capitalized in order to make such access to subsidies possible. On the other hand, if they view the accompanying corporate governance intrusion by the government as unwelcome and possibly even stigmatizing, then they would take steps to avoid it, which makes the adverse ex ante effect on the bank's capitalization incentive a less serious concern.

This raises the following research questions that we examine empirically. First, do banks view the access to government bailout funding and the affiliated director appointments favorably or unfavorably? In particular, do banks try to avoid these appointments? This also addresses the related question of ex ante incentive effects and whether the government directors play a meaningful role in the governance of the bank or are viewed as ceremo-

4. As we discuss in Section 2.1, the vast majority of capital assistance by the Treasury involved preferred stock, so the payments made to the Treasury were dividend payments. There was a small fraction of the assistance capital that was provided in the form of subordinated debt; in this case, the payments on the securities owned by the Treasury were in fact interest on debt. For expositional convenience, we will sometimes slightly abuse terminology and refer to all payments as dividends, even though some were interest. 
nial appointments. Second, how does the appointment of government directors affect the performance of the bank? This addresses the related question of ex post incentive effects.

We find the following main results. First, we find that banks strongly attempt to avoid triggering the appointment of government directors on their boards. We show that there is a clear discontinuity in the empirical distribution of missed dividend payments to the Treasury between five and six. While the number of bank-quarters with five missed dividend payments is $3.4 \%$ lower than the number of observations with four missed dividend payments, the empirical frequency drops by $24 \%$ when we move from bank-quarters with five missed payments to bank-quarters with six missed payments. We then analyze the relationship between the number of missed payments to the Treasury and its average change to the next quarter.

To have a theoretical foundation for this relationship, we develop a simple model in which the bank manager (CEO) enjoys a private benefit of control and stands to lose it with government directors on the board. The bank gets equity funding from the government and, as per the structure of the $\mathrm{CPP}$, it must make dividend payments to it, with the stipulation that the government will appoint directors on the board if a certain number of dividend payments are missed. It takes (privately observed) costly effort by the manager to generate the cash to make the dividend payments to the government in any period. This model generates the prediction that the manager will work harder to generate the cash to make a dividend payment as the bank gets closer to the threshold number of missed payments that will trigger the appointment of government directors. Consequently, the probability of a missed dividend payment will decline most precipitously right below the threshold for government director appointments, and be higher on either side of the threshold.

We then take this prediction to the data. For banks that have missed one, two or three dividend payments to the Treasury, we find that the number of missed payments increases on average by $0.77-0.80$ in the next quarter. Banks that have missed four dividend payments are more "disciplined" and the average change in the number of missed payments drops to 0.64. For banks that have missed five payments (these are the banks on the edge of the precipice), the number of missed payments increases, on average, by only 0.42 . Once the 
bank has crossed the Rubicon and missed six payments, the average change in the number of missed payments rises sharply, to 0.77 . These findings are consistent with our theoretical framework and are validated by a more rigorous econometric analysis, where we examine their statistical robustness and control for potential confounding variables ${ }^{5}$.

We are a priori agnostic about why bank managers may dislike Treasury appointments. It may be because they believe that the appointees may be bureaucrats who will negatively impact board decision-making and diminish bank value. Alternatively, managers may be protecting their own interests, fearing that the new directors may reduce managerial entrenchment and rent-seeking. We will let the data speak to this issue, which takes us to our second research question. We find that poor performance is correlated with the likelihood of missing dividend payments to the Treasury, and the appointment of government directors improves performance. Banks that have missed at least one dividend payment (these comprise roughly one-third of the institutions in our sample) are less profitable (based on ROA and ROE) and have lower capital ratios than banks that have not missed any dividend payments to the Treasury, and profitability improves after government-appointed directors are on the board.

We then examine the consequences of actual director appointments. Of the 162 banks that, at any given point in time, become eligible for a director appointment, 16 do receive at least one Treasury-appointed director. We match "treated" banks with institutions in the CPP that are similar in terms of numerous observable characteristics. After government directors come on board, ROA and ROE both improve, and the ratio of non-performing loans to total loans declines. In addition, treated banks are less prone to engage in earnings management. We do not observe differences in the trends of these variables prior to the appointments, suggesting that our matching procedure does a good job addressing selection concerns. Moreover, there is some evidence of agency costs declining as well, since CEO compensation drops after the government directors join the board. We buttress this analysis

5. As we discuss in Section 2.1, there are also other provisions applying to banks that miss dividend payments to the Treasury. For example, banks recapitalized with cumulative preferred shares were not allowed to make dividend payments on common shares as soon as they missed even a single dividend payment on the preferred shares. Importantly, no other restriction takes effect at the 6-missed payment cutoff, allowing us to isolate the effect of the threat of directors' appointments from other provisions of the CPP. 
with an examination of short-run and long-run buy-and-hold returns of the treated banks in our sample after Treasury director appointments. We find that the banks treated with the Treasury director appointments outperform control banks.

Interestingly, we find that the Treasury did not always exercise its option to appoint directors when a bank missed six dividend payments. Rather, it did so selectively. This suggests that the U.S. government perceived a cost to intruding in the corporate governance of the delinquent banks, which included, but was not limited to, the cost of a relatively expensive and time-consuming review and selection process ${ }^{6}$. The government thus traded off this cost against the benefit of the intrusion, and having the ex post flexibility to do this is consistent with one of the three principles of optimal prudential regulation outlined in Greenwood, Hanson, Stein and Sunderam (2017). We discuss this issue in Section 4.5 and document that the strongest predictor of the government's decision of whether or not to exercise its option was bank size. This suggests that the government prioritized banks likely to have greater systemic importance.

We then use a "case study" to further test the hypothesis that - the post-appointment improved performance notwithstanding - banks participating in the CPP did not view Treasury director appointments on their boards as a favorable event. For this test, we utilize what we call the "Vikram Pandit shock". In February 2009, Citigroup asked the Treasury, which had previously invested $\$ 20$ billion of TARP funds in Citigroup, to convert a portion of its preferred stock to common equity to strengthen its capital structure. At the same time, Citigroup agreed to alter the Board of Directors to have a majority of independent directors. Six directors were appointed, three of whom had previous experience in government or banking supervision. Another appointee was Michael O'Neill, a former bank CEO who would later be appointed Chairman of the Citi board; two years earlier, he had been considered a top contender for the Citi CEO job that ultimately went to Vikram Pandit. On October 15, 2012, O'Neill told Pandit that the board had lost confidence in him and that he should resign as CEO, which he did the following day ${ }^{7}$. This suggests that at

6. As the "FAQ" available on the Treasury website report, the Treasury first hired executive search firms to find a list of suitable candidates and then reviewed and selected the members from the list. The Treasury had developed criteria and protocols to guide the review and selection process.

7. Silver-Greenberg and Craig (2012) report: “The background of the story is that O'Neill had pretty much 
least some of these directors played an active role in corporate governance, and that bank CEOs may be averse to having them on the board.

We next analyze the impact of the "Vikram Pandit shock" on the behavior of the other banks in the CPP. We do so by examining for each quarter the number of banks that are in the CPP and that are eligible for director appointments, which are the banks whose CEOs are arguably more under "threat" of being fired. We focus on a $(-2,+2)$-year window surrounding Q4-2012, the quarter of the "Pandit" shock. We find a sharp discontinuity in the rate of growth of the number of "undisciplined" banks in the program, whose number starts dropping precisely after Pandit's firing. We further show that the rate of exit from the CPP due to redemption of the shares owned by the Treasury increases rapidly after this event, consistent with our hypothesis that Pandit's firing made the consequences of unfriendly boards more salient to CEOs of banks funded by the Treasury. Moreover, we do not observe a similar pattern for banks that are not eligible for director appointments. For these banks, the exit rate, if anything, appears to decline over the same time window.

Our results have policy ramifications that deserve further study. They imply that there is a mechanism available to the government for bailing out banks through (possibly subsidized) capital infusions while still limiting both ex ante and ex post moral hazard. Moreover, the threat of firing the $\mathrm{CEO}$ is powerful and can induce voluntary exits from the program that achieve the goal of private recapitalization of banks. In this sense, the CPP helped the government to force banks to actively recapitalize after a negative systemic shock, an outcome that Greenwood, Hanson, Stein and Sunderam (2017) state as one of the three principles of effective prudential regulation. Thus, our analysis suggests that rather than focusing on how to avoid bailouts, which may be unavoidable given a systemic shock to financial stability, there could be a focus on designing mechanisms to limit/eliminate moral hazard with bailouts.

Our paper is related to many strands of the literature. One strand is the literature

been planning Pandit's ouster since he got there. There had always been tension, in part since O'Neill himself had been a contender for the CEO job back in 2007. As Chairman, O'Neill had been slowly working over each board member, building the case to let Pandit go. A dispute with the Federal Reserve from last March - in which Citigroup was denied the ability to start paying a dividend - was a major point in O'Neill's favor, allowing him to argue that Citi's frosty relationship with regulators was a major impediment." 
specifically on TARP and the CPP. A good overview of these topics is provided by Bayazitova and Shivdasani (2012), who study applications to the CPP program and the dividend payment behavior of banks. They find that weak banks were more likely to enroll in the program, but this participation was not perceived by investors as a negative signal. Berger and Roman (2020) and Calomiris and Khan (2015) provide detailed descriptions of the institutional details of these programs. Wilson and Wu (2012) examine banks that exited the program early and argue that it was due to restrictions on CEO compensation and diminished ability to raise private funding. Duchin and Sosyura (2014) provide evidence that banks that received assistance under TARP made riskier loans, i.e., there was ex post (risk-shifting) moral hazard. A significant difference between this literature and our paper is that we focus on how the anticipation of the change in corporate governance due to government director appointments in the CPP influences bank behavior both prior to and after these appointments.

This paper is also related to the broader literature on bank bailouts, which are generally considered socially costly. These costs are analyzed in a number of theoretical papers. Bailouts may be used by benevolent governments to avoid costly bankruptcies in otherwise efficient private markets, and may thereby introduce inefficiencies where none existed (Chari and Kehoe (2016)), alter the level of liquidity in the economy (Diamond and Rajan (2002); Keister (2016)), and induce excess leverage, especially in large banks (Dávila and Walther $(2020))^{8}$. On the empirical side, Dam and Koetter (2012) provide evidence that changes in bailout expectations affect the probability of official distress of German banks.

These costs notwithstanding, it is widely recognized that bailouts may sometimes be unavoidable, so numerous papers focus on their optimal design and the consequences of different design choices. Casey (2015) provides a framework for how bailout regulation should be structured. Philippon and Skreta (2012) and Tirole (2012) study the cost-minimizing interventions to restore lending and investment when markets fail due to adverse selection. Philippon and Wang (2021) develop a model in which a tournament among banks that may face the prospect of future bailouts can be designed ex ante to reduce the moral

8. Bianchi (2016), instead, finds that systemic and broad-based bailouts can be efficient, as moral hazard effects are limited. 
hazard engendered by these recapitalizations. Philippon and Schnabl (2013) show that a combination of preferred stock plus warrants reduces opportunistic participation by banks not in need of recapitalization. Acharya and Thakor (2016) develop a model in which the government bails out some banks to prevent "contagious liquidations" caused by creditors of even healthy banks liquidating their banks because they draw adverse (and sometimes erroneous) inferences about the values of commonly-held assets based on the liquidations of other banks. Clayton and Schaab (2020) find that in the optimal regulatory regime, bail-ins generally dominate bailouts.

In sharp contrast to these theoretical papers that do not consider the (temporary) appointment of government directors as an incentive alignment tool, we argue that a potentially fruitful mechanism for the government to bail out banks with capital is to require in exchange an active role in bank governance along the lines of the $\mathrm{CPP}^{9}$. This connects our paper to the earlier research dealing with policy prescriptions related to the post-crisis corporate governance of banks (e.g. Macey and O'Hara (2016), and Mehran, Morrison and Shapiro (2011)).

The rest of the paper is organized as follows. In Section 2 we discuss the relevant institutional details related to TARP and the CPP, and also describe the data. Section 3 presents a simple model and descriptive evidence on banks' dividend repayment behavior. Section 4 presents the main empirical results of the paper. Section 5 concludes. Additional information, including the proof of a proposition in the theoretical model, institutional details of the CPP, information on the directors appointed by the Treasury, and additional results and robustness tests, are provided in the Appendices.

\section{Institutional Context and Data}

In this section we provide a description of the relevant institutional details and the data.

9. Berger, Nistor, Ongena and Tsyplakov (2020) empirically examine the restrictions imposed on assisted banks following recapitalization. Their analysis does not examine the separate effect of governance intrusions via government board appointments but rather lumps this together with other restrictions, like those on executive pay and dividend payments, to construct a "harshness" index. 


\section{$2.1 \quad$ Institutional Context}

During the 2007-09 financial crisis, the United States Treasury set up the Troubled Asset Relief Program (TARP) to stabilize the U.S. economy. TARP included government funding for several programs that focused on different sectors of the economy. Among them were capital-infusion programs targeted at banks, such as the Capital Purchase Program (CPP), which began in October 2008, and the Community Development Capital Initiative (CDCI), which began in 2010. The CPP was by far the largest capital-infusion program, and had the objective of promoting the recapitalization of banks. 707 banks participated in this program and got recapitalized between October 2008 and December 2009, for a total of $\$ 205$ billion invested by the Treasury.

Under the CPP, the U.S. Treasury offered to buy three different types of securities from participating institutions - cumulative preferred shares ( $81 \%$ of the banks in the program), non-cumulative preferred shares (12\%), and subordinated debt $(7 \%)$. For the preferred shares, the Treasury also acquired warrants for newly issued equity of the institutions. The maximum amount an institution could receive from the Treasury was the minimum of $\$ 25$ billion and $3 \%$ of the institution's total risk weighted assets.

The securities could be redeemed subject to certain restrictions, which were changed by the American Recovery and Reinvestment Act (ARRA) in February 2009 (see Wilson and Wu (2012)). Prior to the ARRA, participants could redeem the shares in the first three years after the recapitalization only through newly issued equity, whereas post-ARRA, redemption was also possible without issuing equity, subject to regulatory approval.

Given their structure, the three types of securities were senior to the participating institution's common stock in terms of dividend payments and cash flow rights. The dividend payments on the preferred shares were to be made quarterly, and the payment was set at $5 \%$ per annum for the first 5 years and $9 \%$ thereafter. Interest rates on the subordinated debt were $7.7 \%$ and $9 \%$, respectively ${ }^{10}$. Missing three dividend payments put the respective institution under "enhanced" monitoring by the Treasury.

10. See "Initial Report to the Congress" from the Office of the Special Inspector General for the Troubled Assets Relief Program, July 21, 2009. 
The U.S. Treasury included an additional covenant related to the appointment of board directors. If the bank missed six quarterly dividend payments, the Treasury had the option to appoint of up to two additional board directors. These directors would be paid by the bank and were supposed to act in the best interests of the bank and all its shareholders ${ }^{11}$. In 2010, the Treasury announced that board directors appointments would be prioritized for institutions in which it had invested more than $\$ 25$ million. Since the announcement was made only after the banks had entered the program, there is no concern about "selection into the treatment". To verify that, in Appendix-Figure A1 we plot the empirical distribution of the funds granted to CPP banks (see Appendix A4). While there is a spike in the distribution at $\$ 25$ million, we find similar, or larger, spikes for any multiple of $\$ 5$-million, suggesting that institutions tended to round their funding needs to multiples of $\$ 5$ million. Thus, as expected, banks could not foresee that funding requests above $\$ 25$ million could potentially lead to additional monitoring.

For cumulative preferred shares, a bank that missed a dividend payment on the CPP preferred stock was not allowed to distribute dividends to common shareholders until all the missed preferred dividend payments were made. In similar vein, the option of the Treasury to appoint board directors could be extinguished only after all missed dividend payments had been made. If banks disliked such corporate governance intrusion by the government, then these features provided banks with strong incentives to make up as soon as possible all the missed dividend payments after crossing the threshold of six missed payments, as long as their financial condition permitted it.

For non-cumulative preferred shares, the restriction was weaker but still significant. The bank simply had to make the latest dividend payment on the CPP preferred stock in order to be allowed to pay common stock dividends. However, the Treasury's option to appoint board directors after missing six dividend payments was abrogated only if dividends on the preferred shares were paid for four consecutive periods.

Banks funded with subordinated debt faced the same mechanism that was used with

11. If the institution missed five dividend payments, the Treasury could ask for permission to send a (nonvoting) observer to board meetings. However, CPP institutions had the option to reject Treasury observers, which they did in several cases. 
cumulative preferred stock, meaning that a missed interest payment to the Treasury would prevent them from distributing dividends to common shareholders, and that six missed interest payments would give the Treasury the option to appoint up to two directors. Given the similarity of the schemes and the fact that only $7 \%$ of banks received funding through subordinated debt, throughout the paper we will use "dividend payments" to refer to both dividend payments on the CPP preferred stock and interest payments on the subordinated debt $^{12}$. See Appendix-Table A1 (Appendix A2) for a summary of the relevant information about the types of securities used in the CPP.

\subsection{Data}

We now describe the data sources used in this study. We begin with the data on the dividend payments on CPP securities, which we obtain from the monthly Interest and Dividend Reports available on the Treasury website ${ }^{13}$. These reports list the dividend payments made by each participating institution as well as the outstanding number of missed payments. We also extract actual director appointment dates.

Although the CPP program started in October 2008, the first report was made available only in May 2009, whereas outstanding missed dividend payments are reported from July 2010 onward. To fill the missing observations on the "stock" of outstanding missed dividends before July 2010, we count all the missed payment events and backfill to match the number of missed dividends in July 2010, taking repayments into account ${ }^{14}$. We complement this dataset with information available in the TARP Transaction Reports on program entry and exit of participating institutions. Out of the 707 participating institutions, 11 had already exited the program before or on May 2009, leaving 696 banks with dividend payment data in our dataset. To ensure that our result are not being driven by defaulting banks with no option to make any payment, we restrict the analysis to banks that, beyond being in the

12. Excluding banks funded through subordinated debt from the sample, as well as banks with noncumulative preferred shares, does not affect our results.

13. Available at the following url:

https://www.treasury.gov/initiatives/financial-stability/reports/Pages/

Dividends-and-Interest-Reports.aspx

14. Results are very similar if we do not fill in the missing observations and include only observations from July 2010 onward. 
program, did not file for bankruptcy.

Annual and quarterly balance sheet and income data covering the time period from 2005 until 2019 are obtained from SNL Financials. We rely on the U.S. Regulated Depository dataset due to its broader coverage. We match the institutions in the CPP by name, city and state with banks in the SNL data flagged as being in the TARP program. Out of 696 CPP institutions, we match 684 banks, of which 569 have non-missing quarterly financial data. There were 162 banks that had, at some point, missed at least 6 payments, and 16 received at least one board appointment.

To analyze the implications of this rule on executives' turnover and compensation, we use BoardEx and SNL data on director and executive positions and their compensation for the period 2007-2019. Fuzzy matching is applied on standardized names to identify the same person in both datasets, and each match is manually checked. To further fill gaps in the panel and extend our dataset, we also hand-collect data using FR Y-6 filings from the Federal Reserve and DEF 14A filings from SEC and FDIC.

The final dataset is an unbalanced panel for the period 2007-2019 incorporating financial data, information on CPP dividend payments, and board members and executives as well as their compensation, when available.

\section{Descriptive Evidence}

In this section we begin with a simple theoretical model which shows how the likelihood of government-appointed directors can influence the bank's dividend payment strategy. The purpose of the model is mainly to sharpen the intuition for the results of the empirical analysis. Specifically, we make predictions regarding bank behavior under the CPP provisions but do not make normative statements. We also do not take a stand on how an "optimal" mechanism should be designed. Then we present the summary statistics and some graphical evidence. 


\subsection{A Simple Model}

We model the bank's dividend repayment behavior to derive a relationship between the outstanding number of missed dividend payments to the government and the likelihood of missing an extra payment

The time horizon is infinite and the periodic discount rate is $\beta$. In every period, the bank has sufficient funds to make the dividend payment with probability $e$. The manager of the bank can affect this probability by expending effort at a privately-observed cost $c(e) \equiv k e^{2} / 2$. The effort cost $c(e)$ may be thought of as the work the bank manager has to put into risk management and in preserving funds to overcome potential liquidity shortfalls. The manager of a bank without a Treasury-appointed director enjoys a private benefit $B$. The idea is that government-appointed directors may deny the bank's CEO operating flexibility and perks that directors hand-picked by the CEO would not ${ }^{15}$. To simplify the analysis, our theoretical framework differs from the real-world setting in two respects. First, we assume that the bank cannot make extra payments to make up previously missed dividend payments. Hence, at any point in time, the only two options available to the manager are making or missing the dividend payment. Second, we assume that once the number of missed payments reaches a cutoff $N^{*}$, the private benefit $B$ is lost forever, which can be interpreted as a director chosen by the Treasury being appointed with probability 1. We make the parametric assumptions $k>4 \beta^{2} B$ and $k>\beta B /(1-\beta)$, which ensure the existence of a real and unique solution.

Let $n$ be the number of missed dividend payments. We prove in Appendix A1 the following simple result.

Proposition 1. The probability of missing an additional dividend payment is equal to 1 if the number of missed payments is $n \geq N^{*}$. It is decreasing in $n$ if $n<N^{*}$.

Proof. See Appendix A1.

15. Huang, Maharjan and Thakor (2020) provide evidence that disagreement between the CEO and the Board of Directors (representing shareholders) is of first-order importance in determining the CEO's operating flexibility and the relationship between firm performance and CEO turnover. 
The first part of the proposition is straightforward: Once the cutoff $N^{*}$ has been crossed, the manager has no incentive to make any payment, as a positive $e$ will generate an effort cost without any benefit for the manager. In Appendix A1, we show that the optimal effort $e^{*}$, and hence, the probability of making a payment for $n<N^{*}$, satisfies:

$$
e^{*}=\frac{\beta\left(V_{n}^{*}-V_{n+1}^{*}\right)}{k}
$$

where $V_{n}^{*}$ is the value function, in equilibrium, of a bank that has missed $n$ dividend payments. When deciding whether to exert an additional unit of effort, the manager trades off the benefit of an increase in the likelihood of remaining in office the next period with $n$, rather than $n+1$ missed payments, against the cost of exerting effort. We show that $V_{n}^{*}-V_{n+1}^{*}>0$ and that this difference is increasing in $n$. Intuitively, missing a payment when a bank is approaching the cutoff $N^{*}$ can be very costly for the manager, as it makes the likelihood of eventually losing the private benefit $B$ approach one. Hence, $e^{*}$ is increasing in $n$ and, as a result, the probability of missing an extra dividend payment $1-e^{*}$ is decreasing in $n$ for $n \leq N^{*}$. Figure 1 below plots the relationship between the number of outstanding missed payments and the average change in missed payments in an example with $N^{*}=6$. As we will see in Sections 3.4 and 4 , it captures well the qualitative patterns of the data.

Figure 1 goes here

\subsection{Going Beyond the Model: Some Remarks on the Incentive Effects of Bailouts}

While the focus of our theoretical model and empirical analysis is on the Treasury's option

to appoint directors on the bank's board after six missed dividend payments to the Treasury and the incentive effect of this on the bank's manager, it is important to note that this was not the only regulatory intervention that mattered to banks. Every recapitalization via the Treasury's purchase of claims on the bank involved heightened regulatory scrutiny in various states of the world prior to the six-missed-payments threshold. For instance, three missed 
dividend payments led to "enhanced monitoring" by the Treasury, and five missed payments allowed the Treasury to send observers to board meetings (although only with the agreement of the bank). Moreover, missing preferred stock dividend payments also meant no common stock dividends could be paid. Thus, missing any dividend payment on the preferred stock purchased by the Treasury was costly for bank CEOs, with the biggest "hammer" being dropped on the bank when it missed six payments.

One implication of this is that there were no incentives for bank managers to play strategic games with the government, such as deliberately missing preferred stock dividends payments in order to create cash stockpiles for other uses and then making sure that only the event of the sixth-missed-payment was avoided. In other words, the structure of the government's contract under the CPP appears to have been designed to incentivize banks to make all their dividend payments, with the strongest incentive being to not miss six payments.

\subsection{Descriptive Statistics}

Panels A and B of Table 1 present descriptive statistics for the main variables used in the analysis. Panel A includes our entire starting sample of 569 banks and 6,808 bank-quarter observations.

The number of missed payments to the Treasury is measured at the end of the quarter and indicates the total missed dividend payments a bank is facing at that point in time. Each quarter the bank has the choice to pay a dividend (leaving the number of missed dividends unchanged with respect to the previous quarter) and even repay all or a fraction of the previously missed dividends (reducing the number of missed dividend payments with respect to the previous quarter), or miss a dividend payment (increasing the number of missed dividends by one with respect to the previous quarter). Because of this, $\Delta$ Missed payments, the quarter-to-quarter change in missed dividend payments, can be equal to one, zero, or be a negative number.

As for performance measures, we report ROA and ROE. ROA represents net income over average total assets (i.e., beginning plus ending assets divided by two) in percentage 
points. ROE represents net income over average total equity, also in percentage points ${ }^{16}$. NPLs/Loans is defined as non-accrual and restructured loans as a percentage of total loans and leases. Log(Revenues) represents the logarithm of the sum of net interest income, noninterest income, and gains on sales of securities. We also report three different capital ratios. The leverage ratio represents the tier 1 capital as a percentage of adjusted average assets. The risk-based capital ratio represents total regulatory capital as a percentage of risk-adjusted assets. The tier 1 capital ratio represents core capital (tier 1) as a percent of risk-adjusted assets. Finally, listed is an indicator variable for the company being publicly listed.

The average number of missed payments is 2.42. The distribution is skewed, with a median of 0 and a $99^{\text {th }}$ percentile equal to 24 missed dividend payments. The mean of $\Delta$ Missed payments is 0.25 (the median is equal to 0 ).

In Panel B, we zoom in on the banks with at least one missed payment (196 banks), and focus on the bank-quarters where at least one dividend payment is missed, which represents about one-third of the sample (2,082 observations). It is immediately apparent, from comparing Panels A and B, that banks with at least one missed payment are much less "disciplined," as their average change in missed payments is 0.73 (median equal to 1). However, the bottom percentile of the distribution is -5 , suggesting that some banks are indeed successful in reducing the stock of outstanding missed payments.

Not surprisingly, banks with at least one missed payment are less profitable, with average ROA and ROE equal to $-0.83 \%$ and $-16.11 \%$, respectively, relative to full sample means of $-0.24 \%$ and $-5.06 \%$. They are also slightly less likely to be publicly listed (38\%, relative to $46 \%$ in the full sample). Interestingly, however, banks with at least one missed payment have, on average, lower leverage and comparable risk-based capital ratio and tier 1 risk-based ratio.

16. These variables are the items ROAA and ROAE, respectively, in the SNL database. 


\subsection{Graphical Evidence}

In this section we provide some preliminary descriptive evidence regarding the behavior of banks included in the CPP program. We start by showing the distribution of missed dividend payments to the Treasury for each bank-quarter. As discussed in the previous section, $69 \%$ of the banks in our sample have zero missed payments. For clarity, we exclude them from the figures presented in this section, but we include them in the econometric analysis that follows.

For each bank-quarter, we count the number of missed payments. The histogram in Figure 2 shows that, of the remaining 2,082 observations, 1,134 crossed the six-missed payments threshold $(55 \%)$. The histogram also shows a clearly decreasing pattern, with the frequency of observations declining almost monotonically with the number of missed payments.

Figure 2 goes here

While the distribution is relatively smooth, Figure 2 also displays a clear "jump" between the five- and six-missed payments bars, with the empirical mass dropping discontinuously. To give a sense of the magnitude of the jump, the number of observations drops by $3.8 \%$ between the four- and five-missed payments bars and by $24 \%$ between the five- and sixmissed payments bars (from 176 to 133 observations).

This graphical evidence is consistent with our hypothesis: if managers dislike board appointments by the Treasury, they try strenuously to avoid hitting the six-missed payments threshold. As a result, once they miss five payments, they try avoiding missing an extra payment and may make additional payments to move far away from the threshold that could trigger the appointment of a director.

An alternative way to examine the effect of managers' incentives, motivated by the theoretical analysis presented in Section 3.1, is to inspect the change in the number of missed dividend payments between two consecutive quarters. If the bank does not miss a payment at time $t+1$, this difference will, of course, be equal to 0 . Conversely, the difference will be equal to 1 if the bank misses a dividend payment in quarter $t+1$. Finally, this difference can be negative if the number of missed payments drops, an event that will 
occur if the bank not only makes a payment at time $t+1$ but also reduces the stock of outstanding missed payments by making some overdue payments left from previous periods.

Figure 3 plots the difference between the number of missed payments between quarters $t+1$ and $t$ conditional on the outstanding number of missed payments at time $t$. For clarity, we "bin" observations with more than 10 missed payments in a single column and, as before, exclude banks with no missed payments. The figure shows that, despite the costs associated with it (see Section 3.2) missing dividend payments is not unusual. The average change in the number of missed payments is always positive, suggesting that, on average, the number of outstanding missed payments increases in the following period. The extent of the increase is, however, highly heterogeneous across banks.

Figure 3 goes here

Starting from the left, we see that for banks that have missed one, two, or three payments, missed payments increase, on average, by $0.77-0.80$. This suggests that for these banks the cost of missing an extra payment is low, as the six-missed payments threshold is still relatively far. The average change in missed payments drops quite sharply for banks having an outstanding backlog of four missed payments. For these banks, the average change is 0.64. Intuitively, the manager trades off the benefit of avoiding a cash outflow (the dividend payment) against the cost of getting closer to the six-missed payments threshold. The lowest average change is observed for banks that have already missed five payments: for these banks, the number of missed payments increases, on average, only by 0.42. An additional missed payment will trigger the possibility of the appointment of a director by the Treasury. Hence, managers of these banks have the strongest incentive to not increase, or to reduce, the outstanding number of missed payments.

Interestingly, the average change in the number of missed payments increases substantially after a bank has crossed the six-missed payments threshold, consistent with our hypothesis and with the model of Section 3.1. Once the bank has missed six or more payments, the cost of missing an additional payment is relatively small, as making the required payment in period $t+1$ would not suffice to eliminate the risk of having the Treasury appointing 
a director.

\section{Empirical Evidence}

In this section we provide the results of our empirical analysis.

\subsection{Prospect of Government-appointed Directors and Bank Behavior}

Following up on the descriptive evidence of Figure 3, we now more formally test whether the possibility of the appointment of a board director by the Treasury affects the dividend payment behavior of banks in the CPP program. Specifically, we estimate the following model:

$$
\Delta \text { Missed }_{i, t+1}=\sum_{j} \beta_{j} \times \mathbb{1}\left(\text { Missed }_{i, t}=j\right)+\delta^{\prime} X_{i, t}+\varepsilon_{i, t+1}
$$

where $i$ indexes banks, $t$ indexes quarters, $X$ is a vector of control variables which include quarter fixed effects, and $\varepsilon$ is an error term. Missed is the number of missed dividend payments to the Treasury and $\Delta$ is the first-difference operator, so that $\Delta$ Missed $_{i, t+1} \equiv$ Missed $_{i, t+1}-$ Missed $_{i, t}$; i.e., it represents the change in the number of missed dividend payments between two quarters. Our coefficients of interest are the $\beta_{j} \mathrm{~s}$, which measure the expected change (relative to the omitted category) in the number of dividend payments between quarters $t+1$ and $t$ conditional on having missed $j$ dividend payments up to quarter t. As in Figure 3, we bin together all firms having missed more than ten dividend payments (i.e., $j>10$ ). To avoid collinearity, one of the $\beta$ coefficients needs to be set equal to zero. We exclude the coefficient $\beta_{5}$, so that all the coefficients can be interpreted as measuring the expected change in the number of missed payments relative to banks that have missed five payments.

Figure 4 plots coefficients obtained after estimating (2), together with $95 \%$ confidence intervals, without any control variables. Standard errors are clustered at the bank level. First, we find that banks with zero outstanding quarterly payments are by far the most 
"disciplined" group of banks, with a very low likelihood of missing a payment in $t+1$ (just 3.7\%). This is not surprising. As discussed in Sections 2.1 and 3.2, banks that sold cumulative preferred stock to the Treasury (which constitute the majority of our sample) were prevented from paying dividends on common stock and faced other costs as well - in terms of greater regulatory scrutiny - if they missed even a single preferred stock dividend payment.

However, banks with at least one missed payment are substantially more likely to miss additional payments, which also makes economic sense. Given that banks are averse to missing any dividend payment, a missed payment signifies a weakness in the bank's financial condition that forces the manager's hand, and indicates an elevated likelihood of future missed payments. Specifically, $\beta_{1}, \beta_{2}$, and $\beta_{3}$ are all positive and statistically significant. This means that we can reject the null hypothesis that banks with 1, 2, and 3 missed payments and banks with five missed payments have the same expected change in the number of missed payments. The coefficient drops in magnitude and becomes statistically insignificant for $j=4$ : as banks get closer to the six-missed payment threshold, they become more reluctant to increase the backlog of missed payments further. The coefficients $\beta_{j} \mathrm{~s}$ are again sizeable and positive, and are all statistically significant for $j \geq 6$, except for $\beta_{9}$, which is more noisily estimated. Overall, this evidence suggests that the findings discussed in Section 3.4 are statistically robust.

Figure 4 goes here

Table 2 reports the coefficients estimated by using different variations over (2). Column 1 simply reports the value of the coefficients presented in the plot of Figure 4. Column 2 includes time fixed effects. To elucidate the purpose of this test, suppose that some unobserved event had affected banks' dividend payment policy around the time in which most institutions had missed just five payments (say, the announcement of tougher monitoring for banks in the CPP). In this case, the inclusion of time dummies should absorb most of the variation exploited by the specification estimated in column 1 . However, there is substantial heterogeneity in the timing in which different banks approach the six-missed dividend 
payments threshold. Appendix-Figure A2 plots the distribution of year-quarters in which each bank reached five missed payments for the first time (see Appendix A4). We find that there is no "bunching" around a particular time, with the first bank reaching five missed payments in the first quarter of 2010 and the latest exactly four years later. Given this cross-sectional heterogeneity in dividend repayment behavior, the inclusion of time fixed effects in Column 2 has little effects on both the magnitude and the statistical significance of the coefficients.

In Column 3, we further include controls for size and the leverage ratio. Finally, in the "kitchen sink" regression of Column 4, we also include profitability (measured by ROA) the NPL ratio, the risk-based capital ratio, the tier 1 capital ratio, and a publicly-listed dummy. The coefficients on the control variables generally have the expected sign. Smaller and less profitable firms are more likely to miss dividend payments, as well as firms with a higher stock of non-performing loans. More importantly, the vector of coefficients $\beta_{j}$ s is largely unaffected.

In the analysis thus far, we have adopted a fully non-parametric approach. As an alternative approach, we can impose more structure on the econometric design to estimate the size of the discontinuity in $\Delta$ Missed Payments at 6 . We approximate the relationship between the number of missed payments at $t$ and its change between $t$ and $t+1$ by fitting a polynomial, and test whether there is a discontinuity at 6 . Specifically, we estimate the following model:

$$
\begin{gathered}
\Delta \text { Missed }_{i, t+1}=\sum_{k=1}^{K} \alpha_{k} \times \\
\left(\text { Missed }_{i, t}-6\right)^{k}+\mathbb{1}\left(\text { Missed }_{i, t} \geq 6\right) \times \sum_{k=1}^{K} \beta_{k} \times\left(\text { Missed }_{i, t}-6\right)^{k} \\
+\gamma \times \mathbb{1}\left(\text { Missed }_{i, t} \geq 6\right)+\delta^{\prime} X_{i, t}+\varepsilon_{i, t+1}
\end{gathered}
$$

Notice that, while we are following a standard regression discontinuity approach, we are not making the assumption that there is no manipulation of the distribution of missed payments around the cutoff (see Lee and Lemieux (2010)); rather, our approach aims at measuring the extent of this manipulation.

The evidence in Table 2 shows that the relationship between the outstanding number 
of missed payments and its change to the next period varies depending on whether the bank has at least six missed payments (weakly decreasing for banks below the threshold and roughly flat for banks above). Hence, it is important to fit two different polynomials, the degree of which is given by $K$, depending on which side a bank is relative to the cutoff. The coefficient of interest is $\gamma$.

Table 2 goes here

In Table 3 we restrict the attention to a $(-5,+5)$ window around the cutoff of 6 missed payments, and fit polynomials of degree 1 (in columns 1 and 3) or 2 (columns 2 and 4), i.e., $K=1$ or $K=2$. Appendix-Figure A3 shows the fit of both the linear specification and the quadratic polynomial (see Appendix A4). While in columns 1 and 2 we do not include controls, in columns 3 and 4 we include the same control variables considered in column 4 of Table 2. We find that the coefficient of interest varies between 0.37 and 0.68 and is significant at the $1 \%$ level in all the specifications, suggesting, again, a strong effect of the 6-missed payment cutoff on banks' repayment behavior.

Table 3 goes here

\subsection{Matching Analysis: The Impact of Government-appointed Di- rectors}

In this section, we analyze the effect of a director appointment on bank performance. An important caveat of the analysis that follows is that the appointment of a director among potentially eligible firms may not be random. Since we do not have a valid instrument correlated with the likelihood of an appointment, we adopt a matching strategy, where each "treated" firm, that is, a firm subject to the appointment of a director from the Treasury, is matched to control firms based on several observables. If two directors are appointed, we consider the year of the first appointment.

As potential control banks, we select all the banks in the CPP that are never subject to the appointment of directors by the Treasury. An alternative choice of control banks would 
include as potential matches all the regulated financial institutions present in the SNL database. While focusing on such a broad sample would maximize the quality of the match in terms of observable variables, the downside of this approach is that banks that never applied for CPP funds may be different with respect to other (unobserved) characteristics, and yet they would be included in the sample. A second, more conservative, alternative would be to include only banks eligible for a director appointment (i.e., that crossed the six-missed payment threshold) but not selected by the Treasury. Given that only 162 unique banks eventually became eligible for Treasury director appointments, such a restriction on the pool of potential control banks severely reduces the power of our tests. We see our final choice as a compromise between these two alternatives. Reassuringly, the results are not sensitive to the particular sample employed. In Appendix A4, we present tests adopting these alternative sampling restrictions and find qualitatively similar results (see Table A4).

We match treated and control firms based on size (measured as the logarithm of total revenues ${ }^{17}$ ), leverage ratio, the ratio of loans to deposit, and a dummy equal to 1 if the bank is listed. These variables are measured at the beginning of the year of the director's appointment. If two directors are appointed, our "treatment year" is the year of the first appointment. Given that the number of potential control banks is much larger than the number of treated banks, we match each treated bank with (a maximum of) four control banks. For each bank, we select four banks with the closest propensity score, obtained by running a logistic regression of the treated dummy on the matching variables. We impose a maximum difference between the propensity scores of 0.025 .

There were 26 directors who were eventually appointed by the Treasury, and these appointments were spread across 16 banks. Out of the 16 treated banks, 15 have all the variables used for the matching as non-missing, and 12 have at least one matched control satisfying the restriction on the ceiling on the difference in the propensity scores. Appendix A3 presents names of the treated banks, appointment dates, directors' names, and, when available, committee memberships for all the events considered, including those eventually excluded from the final sample. Our final sample includes 56 unique firms.

17. The results are similar if we use the logarithm of total assets instead. 
The results of our matching procedure are reported in Table 4. The first and second columns report the means of each of the four variables used for the matching procedure. The third reports their difference, and the fourth has the $p$-value computed under the null hypothesis of no difference in the means. In Panel A, we find that for the four variables the differences are economically small, and we can reject the null hypothesis at conventional significance levels ${ }^{18}$. In Panel B we present analogous statistics for the outcome variables. Treated banks have a higher NPLs/Loans ratio and lower profitability, as measured by ROA and ROE, although these differences are not statistically significant. Thus, the Treasury appears to have selected relatively poor performers. However, as we discuss in Section 4.3, there are no differences in the trends prior to the director appointment for any of the variables (see Figure 5 and Appendix-Figure A4).

Finally, in Panel $\mathrm{C}$ we also present these statistics for additional variables, namely the ratio of retained earnings to assets, the logarithm of total assets (an alternative measure of size), the loans-to-deposits ratio, the ratio of cash holding to assets, and the logarithm of total funds granted by the Treasury. In no case are the differences statistically significant and are somewhat economically sizeable only for retained earnings-to-assets and cash-toassets. This is not surprising in light of the lower profitability of the treated firms emerged from Panel A.

Table 4 goes here

Given the evidence presented in Section 4.1 on the aversion of bank managers to Treasuryappointed directors, we expect such appointments to not be merely ceremonial. To investigate this further, we next inspect the appointed directors' backgrounds. We collect biographical information on all directors and CEOs from BoardEx, SNL, and internet sources, such as LinkedIn. Interestingly, four out of the sixteen treated banks received an appointment of a director with public sector experience (either the Office of the Comptroller of the Currency, the Federal Reserve, or the Treasury). We also explore whether appointed

18. For the listed status dummy, the matching is exact, meaning that each listed firm is matched with a set of listed control firms with probability 1 and vice versa. However, some treated firms are matched with less than four control firms (due to the ceiling on the difference in the propensity scores), resulting in a small difference in the means of the listed dummy between the two groups. 
directors had any previous joint work experience with the incumbent CEOs. CEO-director ties are associated with executive entrenchment, lower board monitoring, lower market valuation (Fracassi and Tate (2012)) and higher CEO pay (Engelberg, Gao and Parsons (2013)). However, out of the 26 directors who were appointed, we could find only a single instance where a director had a previous employment connection with a CEO of a treated bank, and that too lasting for just one year. Thus, the Treasury appears to have selected directors who were sufficiently independent. In addition, anecdotal evidence suggests that appointees were generally well-regarded by practitioners and industry observers ${ }^{19}$.

We also collected information about board committee memberships from banks' proxy statements to get a sense of the degree of influence the board appointees can realistically exert. We find that fourteen out of nineteen directors for whom we have this information sit on at least one board committee, most frequently the audit committee (ten directors). Interestingly, the Accounting literature emphasizes how more independent audit committees are more effective in monitoring CEO's actions (see, for example, Klein (2002)).

\subsection{Board Appointments and Bank Performance}

To assess the effect of Treasury-appointed directors on firm performance, we estimate the following difference-in-differences model:

$$
Y_{i, t}=\alpha \text { Post }_{i, t}+\beta \text { Post }_{i, t} \times \text { Treated }_{i}+\delta_{t}+\gamma_{i}+\varepsilon_{i, t}
$$

In this equation, Post is a dummy equal to 1 in the year of the appointment and in the following years. Treated is a dummy equal to 1 for firms that are eventually subject to a director appointment. Our coefficient of interest is $\beta$, which measures the change in the outcome variable $Y$ after the director appointment for treated banks relative to the matched control group. For each firm, we keep a symmetric nine-year window around the appointment

19. For example, according to the international law firm Bryan Cave, "Based on the Treasury appointees that we're aware of, the Treasury has identified highly qualified independent bank directors, that can act as a real benefit to the institution they're being appointed to. As a general matter, they tend to be wellcredentialed outside directors, frequently former bank executives that understand the condition of the bank." (Source: "Treasury updates TARP missed dividend report", lexology.com, March 12, 2012.) 
year (i.e., we keep four years before and four years after the director appointment), resulting in a total of 466 observations. All the dependent variables are winsorized at the $1 \%$ level. Standard errors are clustered at the bank level ${ }^{20}$.

The results of this analysis are reported in Table 5. We start in column 1 by focusing on the effect on the ratio of non-performing loans to total loans, a standard measure of the quality of outstanding loans. We find a marked improvement, with a $\beta$ coefficient of -3.44 and significant at the $1 \%$ level. The coefficient is also economically significant, corresponding to over three fourths of the sample standard deviation (equal to $4.48 \%$ ).

Table 5 goes here

Improved bank performance could be due to an improvement in the bank's overall cost management and credit analysis processes, as well as possibly more effective monitoring of bank management by the new directors. It may also reflect a general reduction in the agency costs of the bank. Alternatively, as de facto government representatives, the new directors may seek to make the bank safer by changing its lending policy in the direction of greater prudence and enhanced protection of the safety net. These two scenarios generate different predictions about the effect on the profitability of the bank. In the first case, bank profitability should improve (with no predicted impact on risk), whereas, in the second scenario, the bank's reduction in risk may be obtained at the expense of its profitability.

To distinguish between these two possibilities, we examine the effect of a Treasuryappointed director on bank profitability. We find in Column 2 that the return-on-assets increases by $1.08 \%$, roughly two-thirds of the sample standard deviation (1.60\%). Similarly, we find in Column 3 that the return-on-equity also increases by $14.02 \%$, which is, again, economically significant (sample standard deviation equal to 20.50\%). In both cases, the coefficients are statistically significant at the $1 \%$ level.

We also examine the effect of director appointments on bank risk by looking at the effect on risk-based capital (column 4) and tier 1 (column 5) capital ratios. This is another indirect

20. Throughout, we do not include control variables, as they could be endogenous and bias the results (see the discussion on "bad controls" in Angrist and Pischke (2009), and Gormley and Matsa (2016)). However, if we include lagged values of the variables used for the matching, the results are very similar. We also obtain similar results if we do not include bank fixed effects, but only the "Treated" dummy in the estimation. 
test of whether directors "respond" to the Treasury or to the shareholders. Intuitively, in the first scenario, we would expect these measures of risk to improve. However, in both cases, we are unable to reject the null hypothesis of no effect.

There is evidence that better corporate governance leads to lower earnings management (e.g., Klein (2002)). Thus, another way to test whether governance improves following directors' appointments is to analyze the dynamics of earnings management after the appointment of directors by the Treasury, especially given that many of the Treasury appointees sat on the audit committees of the boards they were appointed to (see Appendix-Table A2). We follow Beatty, Ke and Petroni (2002) to construct a proxy for the abnormal use of loan loss provision, a way in which bank executives can manipulate earnings ${ }^{21}$. Given that such manipulations involve both positive and negative values of accruals (i.e., managers may have incentives to decrease earnings in one year to boost them in the following year), we follow Bergstresser and Philippon (2006) and take the absolute value of the abnormal loss provision as a proxy for abnormal accruals, demeaned and standardized for ease of interpretation. We find in column 6 a statistically significant drop in earnings management following Treasury appointments, with a coefficient that is also large in economic terms and equal to -0.76 . Thus, managers of treated banks appear to have a reduced ability to manage discretionary earnings $^{22}$.

To examine the timing of the effect of a director appointment, we estimate the following event-study regression:

$$
Y_{i, t}=\sum_{k=-4}^{4} \alpha_{k} D_{i, t}^{k}+\sum_{k=-4}^{4} \beta_{k} D_{i, t}^{k} \times \text { Treated }_{i}+\gamma_{i}+\delta_{t}+\varepsilon_{i, t}
$$

Here $D^{k} \equiv \mathbb{1}\left(t=t_{i}^{*}+k\right)$, where $t_{i}^{*}$ is the event year for firm $i$. The coefficients of interest in this design are the $\beta \mathrm{s}$, which capture the evolution of the dependent variable for treated

21. Specifically, we regress loan loss provisions on NPLs, loan loss allowance, real estate loans, commercial and industrial loans, loans to depository institutions, agriculture loans, consumer loans, loans to foreign governments, the logarithm of total assets, and region-year fixed effects. All the loan variables are scaled by total loans. The error term from this regression is used as a proxy for discretionary accruals.

22. Beatty, Ke and Petroni (2002) also consider another measure of earnings management, the abnormal realized security gains and losses. Unfortunately, this alternative measure is missing for about $30 \%$ of the observations. However, consistent with the results of Table 5, when we estimate equation 4 in this smaller sample, we obtain a negative coefficient $(-0.22)$, albeit imprecisely estimated (standard error $=0.30$ ). 
and control banks around the director's appointment. To avoid collinearity, we exclude the dummy corresponding to the year before the appointment. The coefficient $\beta$ s are plotted in Panels A, B, C, and D of Figure 5 for the ratio of non-performing loans to total loans, ROA, and ROE, respectively. The coefficients display the expected pattern. There is no evidence of any pre-trend, whereas an improvement in performance is apparent starting from $k=1$. Notice also that there is no evidence of mean reversion, suggesting that Treasuryappointed directors can have persistent effects. We present similar event-study evidence for risk-based capital ratio and tier 1 capital ratio in Appendix-Figure 44 where, again, we do not find evidence of differences in the pre-trends between treated and control banks. Thus, Treasury directors' appointments do not appear to follow unusual or sudden declines in banks' performance, which could in turn confound the evidence presented in Table 5.

Figure 5 goes here

In Appendix A5, we also present evidence that Treasury appointments appear to affect stock market valuations of treated banks (see Appendix-Table A5). We obtain from banks' 8-K filings the dates of disclosure of the new appointments and find no immediate market reaction, as measured by the three-day cumulative abnormal return. However, we find that treated banks outperform control banks in the following year substantially, by $64-67 \%$. Despite the small sample size, corresponding to the intersection of our sample of 56 banks with the "CRSP" database, which has stock returns for all U.S. publicly listed firms, this result is statistically significant at the $5 \%$ or $10 \%$ level.

\subsection{CEO Turnover and Compensation}

A clear implication of our results of Section 4.2 is that managers prefer to avoid letting the Treasury appoint directors on the boards. Still, as shown in the previous section, their appointment appears to improve bank performance. Hence, they do not appear to hurt shareholders, nor does it seem to be the case that banks' CEOs act as guardians of shareholders' interests against unskilled "bureaucrats". Thus, we hypothesize that Treasury-appointed directors might directly impact managers' payoffs, or private benefits, as in the stylized 
framework presented in Section 3.1. Indeed, according to Mace (1971), directors serve both as a source of advice and discipline. While CEOs may welcome Treasury-appointed directors' ability to provide valuable advice, the reluctance to have these directors on the board likely stems from their potential role in disciplining ineffective management and renegotiating their compensation packages.

We adopt the same empirical framework of equation (4) but estimate the effect of directors' appointments on CEO turnover and compensation. For each bank in our sample, we identify the CEO (or, when missing, the top officer, as indicated in the FR Y-6 filing) and her total reported compensation from the SNL database, complemented with data handcollected from corporate filings. This data collection results in 444 observations for the turnover regressions and 258 for the compensation regressions.

In Column 1 of Table 6, we test whether a director appointment is associated with an increase in CEO turnover. The dependent variable is a dummy equal to 1 if the bank's $\mathrm{CEO}$ in year $t$ is different from the CEO in year $t-1$, and 0 otherwise. We estimate a small and insignificant coefficient, implying a lack of evidence that the CEO's job security is significantly threatened by Treasury-appointed directors.

Another reason why CEOs might dislike Treasury-appointed directors is that they could affect their compensation schemes. While the CPP imposed some restrictions on executive compensation, they were unlikely to fully offset all potential excesses ${ }^{23}$. Treasury directors could be more effective in this respect. For example, Core, Holthausen and Larcker (1999) show that more independent outside directors are associated with lower CEO compensation. In Column 2, we replace the dependent variable with the logarithm of total reported compensation. We estimate a large and negative coefficient, -0.29 , significant at the $5 \%$ level. Hence, there is evidence of a reduction in total pay for CEOs whose banks have government-appointed directors on the board.

23. As Timothy Geithner, the Treasury Secretary between 2009 and 2013, writes: "We had no power to set compensation for most private firms. We had more authority over firms receiving TARP funds, but we couldn't reduce bonuses to levels that the public might find acceptable without unleashing an exodus of talent from those banks, reducing their prospects of navigating their way to safety. In any case, I thought the public's rage on these issues was insatiable. I feared that the tougher we talked about the bonuses, the more we would own them, fueling unrealistic expectations about our ability to eradicate extravagance in the financial industry." (Geithner (2014)) 
Given the compensation restrictions for institutions in the CPP (summarized in AppendixTable A1), one potential explanation for this result is that Treasury appointees might have affected CEO pay not directly but indirectly, for example, by delaying the bank's exit from the CPP. To account for this possibility, in Column 3 we include an "in CPP" dummy, equal to one for banks still in the program during the year. We find, as expected, that this coefficient is negative, large in magnitude $(-0.14)$, and (marginally) statistically significant. However, our coefficient of interest is largely unaffected and retains its statistical significance.

The result that CEO pay drops following directors' appointments is remarkable in light of the fact that Treasury appointees lead to an improvement in bank performance. Indeed, Bennett, Gopalan and Thakor (forthcoming) show that CEO compensation is strongly positively related to ROA and ROE, both of which, as shown in Section 4.3, increase markedly following the Treasury appointments.

As a result, the evidence presented in Columns 2 and 3 may even underestimate the true effect of Treasury appointments on CEO pay. To see that, in Columns 4 and 5 we include contemporaneous ROA and ROE, respectively, as controls. As expected, both of them enter with a positive and statistically significant coefficient. The coefficient on the Post $\times$ Treated variable not only remains negative and significant but increases in magnitude. In Column 6 , where we include both performance variables, the coefficient of interest is -0.38 , roughly one-third higher than the baseline estimate of Column 2 and significant at the $1 \%$ level.

The fact that the fall in CEO compensation is not related to a drop in performance but, rather, to an improvement, helps alleviate concerns that Treasury appointees may push for CEO pay cuts for purely "political" reasons, such as pandering to public indignation over compensation excesses ${ }^{24}$. Inefficient pay cuts may lead to a migration of talent or a reduction in managerial effort. However, the concomitant improvement in profitability suggests that the drop in executive compensation could be explained, at least in part, by a reduction in managerial entrenchment.

24. The most well-known controversy in this respect is related to the AIG decision to pay $\$ 165$ million in bonuses in March 2009, after the government's bailout. The decision of the Treasury not to take legal action was followed by outrage expressed by a number of commentators. 
Table 6 goes here

One possible reason for the improvement in bank performance after Treasury-appointed directors came on board may have paradoxically been the aversion of CEOs to these directors. CEOs may have worked hard to improve performance, so as to raise private capital, facilitate the exit of their banks from the CPP, and get rid of the Treasury appointed board members, given that banks were not required to keep Treasury-appointees on the board after they exited the program. In particular, we are interested in the following question: did performance improve simply because bank managers were so eager to get Treasuryappointed directors, and the stigma associated with them, off their boards (in which case they amount to no more than a human version of a scarlet letter) or did these directors actually contribute something useful themselves?

Although our main conclusion that the CPP was effective in recapitalizing banks while coping with ex ante and ex post moral hazard is unaffected by the answer to this question, it is nonetheless an interesting issue to explore. We address it by examining how many of the bank directors were retained by treated banks after they exited the CPP. If bank managers improved performance just so they could be in a stronger position to raise the necessary private capital to redeem Treasury shares and dismiss the Treasury directors, then we should expect most of these directors to be off the boards right after their banks' exit from the CPP. However, in Appendix-Table A2, we find that, out of 26 appointees, only 3 (employed at 2 banks) leave the bank before or immediately after the bank's exit. As many as 16 directors (employed at 10 banks) remain on the board even after the bank has left the CPP. ${ }^{25}$ This suggests that, regardless of how the bank CEOs felt about them, most of the Treasury-appointed directors were perceived by shareholders to have made valuable contributions to bank performance and did not represent a stigma that they wanted to immediately get rid of.

Thus, while our evidence suggests that CEOs disliked such appointments, in most cases shareholders seem to have a different view. This tension between management and shareholders is not surprising in light of our evidence on earnings management and compensation 25. For the remaining 7 , employed at 4 banks, the exit from the CPP coincides with mergers or bankruptcies. 
(see Tables 5 and 6 ), which shows that the improvement in the performance of the treated banks was due, at least in part, to a reduction in managerial entrenchment.

\subsection{In What Circumstances Did the Treasury Choose to Exercise Its Director Appointment Option After Six Missed Dividend Payments?}

Our analysis shows that the Treasury did not always exercise its option to appoint directors on the bank's board after six missed dividend payments. In fact, this option was exercised in only $10 \%$ of the cases in which six payments were missed.

One reason for this is that the U.S. government has typically been reluctant to get actively involved in the direct governance of banks ${ }^{26}$, and hence prefers to use a combination of prudential regulation tools (like capital requirements), regulatory supervision, and market discipline (by the bank's shareholders and subordinated debtholders) to produce the desired behavior by banks (see, e.g., Mehran, Morrison and Shapiro (2011)).

During the 2007-09 crisis, this reluctance may have been due in part to the desire to let shareholder-owned banks be responsible for their own governance to the extent possible, and in part to not discourage participation in the program by banks. The latter goal was particularly important due to the need to recapitalize banks through government-provided equity and restore the health of the banking system. If banks viewed the cost of participating in the CPP as being exorbitant, even some of those that needed the capital maybe have not opted in, thereby impeding the government's financial stability goal.

This explains why the Treasury did not put in place covenants in the CPP that simply stipulated that the government would fire the bank's CEO in the event that a certain number of dividend payments were missed. Rather, the design of the CPP was such that it allowed the Treasury to weigh the benefits of appointing directors against the perceived cost of direct

26. Top U.S. policymakers have generally been quite explicit about this reticence: "The notion that we should even consider nationalizing a large swath of the banking system as anything but a last resort, just because it felt resolute and cleansing, seemed irresponsible and unwise. If we nationalized a major bank, we would not only own all its legacy losses and risks, which could be hugely expensive for taxpayers; we would own its management issues and compensation messes and who knew what other surprises. Congress would feel like it owned them, too, and would be tempted to interfere in the bank's business decisions for political purposes." (Geithner (2014)) 
government intrusion into the running of the bank and then decide whether to exercise its option. This design feature gave it the ability to observe the specific circumstances for each bank and then determine its optimal course of action. In such a setting, we should expect heterogeneity across banks in terms of whether directors were appointed by the Treasury after six missed payments.

In this section, we examine whether there are observable differences across banks that could explain when the Treasury chose to exercise its option. We focus on the subset of banks that crossed the six-missed payments threshold and examine a set of potential predictors of a Treasury appointment by estimating a probit model. Our sample is a crosssection of banks, and potential predictors are measured at the time in which they cross the six-missed-payments threshold and become eligible for an appointment. ${ }^{27}$

In Column 1 of Table \%, we estimate a probit model with the four variables we use for our matching strategy as predictors and a "board appointment dummy" as a dependent variable. We find that size is the only significant predictor of Treasury appointments. In Column 2 we include a dummy equal to 1 if the total funding amount was larger than $\$ 25$ million, as the Treasury had announced that it would prioritize these institutions (see Section 2.1). However, the coefficient on this variable is insignificant. This is not surprising, given its strong correlation with bank size, as measured by the logarithm of revenues. Finally, in Column 3 we include a more comprehensive set of additional predictors, but the only consistent predictor of board appointments is size. In terms of economic magnitude, we can estimate, using the "delta method", an average marginal effect of $\log$ (Revenues) on the probability of a board appointment equal to $8.2 \%$. These results suggest that the Treasury perceived the benefits of governance intrusions to outweigh the costs primarily in large, and potentially systemically important, institutions.

27. Notice that while 162 banks eventually became eligible for an appointment, our sample size varies between 122 and 111 depending on the availability of the variables employed. 


\subsection{The Effect of the "Pandit Shock"}

We now examine whether the firing of Vikram Pandit had any effect on the other banks that were in the CPP. The idea is that the CEOs of banks that participated in the program may not have fully realized the power or inclination of truly independent directors to dismiss them. This hypothesis is consistent with our finding that, for our sample period, the appointment of these directors did not result in a significant increase in CEO turnover at the treated banks. Nonetheless, the Pandit shock, which occurred three years after the start of the program, may have jolted the CEOs of other banks into recognizing a possibility to which they may have a priori attached little probability weight.

As mentioned in the Introduction, the exchange of Citigroup preferred stock for common stock in February 2009 was followed by a significant reshuffling of its board of directors. Although Treasury did not formally choose the directors, Citigroup's decision to appoint new independent directors was announced by the Treasury at the same time as the exchange decision, so investors perceived the two events as concomitant ${ }^{28}$.

The actual appointments, announced between March and July, strengthened this perception. Three out of six had previously held public offices, and none of them had any private sector connection with Pandit ${ }^{29}$. More importantly, Michael O'Nell was an experienced banker and, previously, a top contender for the Citi CEO job. He would become Chairman of the Board in March 2012, a role that enabled him to oust Pandit in October 2012.

We hypothesize that this event made more salient the consequences for CEOs of having to face board members who are not only independent, but potentially confrontational, thereby causing an increase in the exit rate from the program for banks eligible for director appointments.

As in the previous sections, we start by presenting suggestive graphical evidence. In

28. See "Treasury Announces Participation in Citigroup's Exchange Offering", U.S. Department of the Treasury, press release available at https://www.treasury.gov/press-center/press-releases/Pages/tg41. aspx.

29. Anthony Santomero was a former president of the Federal Reserve Bank of Philadelphia (he resigned in 2011); Diana Taylor was the New York State Superintendent of Banks; Robert Joss was deputy to the Assistant Secretary for Economic Policy at the U.S. Treasury Department. The only connection between either appointee and Pandit reported in the BoardEx "Network" dataset was between him and Diana Taylor, as they were both members of the board of the Columbia Business School. 
Figure 6, we display, for each quarter-end, the total number of banks in the program (in green) and distinguish between banks eligible and ineligible for director appointments (in blue and red, respectively). We restrict attention to the 16 quarters surrounding Pandit's resignation, which occurred at the beginning of the last quarter of 2012. For this analysis we exclude from the sample those institutions whose timing of exit from the program was partially determined by the Treasury. These were banks whose shares were auctioned and banks that transitioned to the "Small Business Lending Fund", a program launched in 2011 and designed to promote lending to small firms ${ }^{30}$.

Figure 6 shows that the total number of banks in the program declines smoothly. The number of non-eligible banks, which dominate the full sample, follows a similar pattern. When we focus on the eligible banks, however, a distinct inverse U-shape pattern emerges. We find that their total number grows as more and more banks cross the six-missed payment threshold, and reaches its peak right before Pandit's resignation, at which time it starts a rapid decline.

Figure 6 goes here

Motivated by this evidence, we test whether Pandit's resignation could have caused a sharp increase in the exit rate of banks that were likely targets of government director appointments. Importantly, we focus only on cases where the bank's exit was the outcome of an active choice by the management. To this end, we hand-collect from the TARP reports information on the exit of each individual bank. We start by excluding exits due to mergers and bankruptcies. Moreover, we exclude exits due to the U.S. Treasury's conversion of preferred shares into common shares. In these cases, the Treasury loses the right to appoint

30. In 2012, the Treasury started to launch auctions to wind down its CPP investments for the shares of 190 banks in the CPP, with deadlines in August and October 2012. As a result, several banks left the program, especially in the first half of 2012. We exclude these institutions because the Treasury clearly affected both the timing of the exit and the selection of the remaining institutions. As for the Small Business Lending Fund, all CPP institutions were allowed to transition to this program if they had missed at most one dividend payment (hence, could not be eligible for a director appointment) and did not have more than 10 billion in assets. Excluding banks that exit the program in these two ways does not qualitatively affect the evidence presented in Figure 6 (The main difference is that the decline in the non-eligible banks over time appears much steeper.) We also collect data on dividend payments by the banks in this program, some of whom were subject to regulations regarding the appointment of directors similar to those of CPP. However, out of 135 banks, only two miss any payments. Thus we are unable to perform a "bunching" test along the lines of those presented in Section 4.1 . 
directors immediately after six missed dividend payments, but, being the holder of shares with voting power, has it the right to vote on the composition of the board. As a result of these restrictions, we retain only exits due to the redemption of shares by the treated institutions.

After applying these filters, we are left with 174 exits due to share redemptions by the CPP institutions, 157 of whom occur over this 16-quarter period (140 for eligible banks and 17 for banks not eligible for a director appointment by the government). We plot the number of exits for each quarter in Figure \%. Given that the number of non-eligible institutions still in the program declines over time (see Figure 6), the number of exits follows a similar downward trend, as shown by the red line. Conversely, exits are less frequent for eligible institutions but display a sharp increase in the last quarter of 2012, after Pandit's resignation, with just two exits occurring in the two years before, and fifteen afterward.

In Table 8, we provide a statistical validation of these results by using a simple differencein-differences design. The number of exits per quarter rises from 0.25 (one every four quarters on average) to 1.875 (almost two per quarter) for eligible institutions. By contrast, it drops from 10.625 to 6.875 for non-eligible banks. Hence, we estimate a 5.375 net "difference-in-difference" effect, significant at the $5 \%$ level $(t$-statistic $=2.23)$.

Figure 7 and Table 8 go here

\section{Conclusion}

We have examined the CCP program under TARP, which allowed the U.S. government to bail out distressed banks by infusing equity capital in them. These capital infusions by the government addressed a major impediment to the recovery of these banks, namely elevated insolvency risk. However, it is well known that bailouts engender moral hazard. We hypothesize that the $\mathrm{CPP}$ dealt with this by having a provision that allowed the government to put directors on the bank's board in case the bank missed a certain number of dividend payments to the Treasury. We argued that whether this was effective in deterring bailoutrelated moral hazard would depend on whether the government-appointed directors were 
"ceremonial" appointees or were directors who would flex their governance muscles. With the former possibility, bank CEOs would be undeterred by the governance intrusion and the prospect of having access to subsidized equity in a future distress state would worsen bailout-related moral hazard. With the latter possibility, moral hazard would be lessened as bank CEOs would be eager to avoid this corporate governance intrusion by the government. This means they would work hard to avoid it, by making the bank strong enough financially to make the dividend payments to the Treasury. We find evidence that is consistent with this latter possibility.

Another tool for the government to deter moral hazard is to use its directors to create the perception that the $\mathrm{CEO}$ would be fired in case the bank was not being managed "appropriately". We show that the firing of Vikram Pandit at Citicorp actually appeared to serve this purpose, as it induced a sharp exodus of banks from the CPP. This exit was enabled by banks buying out the government's equity stake, which meant that private equity was infused to replace the government's investment. Consequently, this ended up being an effective device to get banks to recapitalize and ensure that the government's investment was limited in duration.

We also document that the appointment of government directors led to an improvement in bank profitability and a lowering of earnings management, non-performing loans, and CEO pay. These findings suggest the need for theories that provide conditions under which the kind of bailout mechanism used by the CPP is indeed the optimal mechanism to deal with the ex ante and ex post moral hazard created by the bailout. More generally, these theories could shed light on how the government, taking as a given the inevitability of bailouts during serious financial crises, could design these interventions to minimize the various costs of these interventions while coping with moral hazard. 


\section{References}

Acharya, Viral V., and Anjan V. Thakor. 2016. "The Dark Side of Liquidity Creation: Leverage and Systemic Risk." Journal of Financial Intermediation, 28: 4-21.

Acharya, Viral V., and Tanju Yorulmazer. 2007. "Too many to fail-An analysis of Timeinconsistency in Bank Closure Policies." Journal of Financial Intermediation, 16(1): 1-31.

Acharya, Viral V., Irvind Gujral, Nirupama Kulkarni, and Hyun Song Shin. 2011. "Dividends and Bank Capital in the Financial Crisis of 2007-2009." National Bureau of Economic Research Working Paper 16896.

Angrist, Joshua, and Jorn-Steffen Pischke. 2009. Mostly Harmless Econometrics: An Empiricist's Companion. Princeton University Press.

Bayazitova, Dinara, and Anil Shivdasani. 2012. "Assessing TARP." The Review of Financial Studies, 25(2): 377-407.

Beatty, Anne L., Bin Ke, and Kathy R. Petroni. 2002. "Earnings Management to Avoid Earnings Declines across Publicly and Privately Held Banks." The Accounting Review, 77(3): 547570.

Bennett, Benjamin, Radhakrishnan Gopalan, and Anjan Thakor. forthcoming. "How Are Bankers Paid?" The Review of Corporate Finance Studies.

Berger, Allen N., and Christa H.S. Bouwman. 2013. "How Does Capital Affect Bank Performance During Financial Crises?" Journal of Financial Economics, 109(1): 146-176.

Berger, Allen N., and Raluca Andreea Roman. 2020. TARP and other Bank Bailouts and Bail-ins Around the World: Connecting Wall Street, Main Street, and the Financial System. London, United Kingdom and San Diego, CA:Academic Press.

Berger, Allen N., Simona Nistor, Steven Ongena, and Sergey Tsyplakov. 2020. "Catch, Restrict, and Release: The Real Story of Bank Bailouts." Swiss Finance Institute Research Paper Series 20-45.

Bergstresser, Daniel, and Thomas Philippon. 2006. "CEO Incentives and Earnings Management." Journal of Financial Economics, 80(3): 511-529.

Bianchi, Javier. 2016. "Efficient Bailouts?" American Economic Review, 106(12): 3607-3659.

Calomiris, Charles W., and Urooj Khan. 2015. "An Assessment of TARP Assistance to 
Financial Institutions." Journal of Economic Perspectives, 29(2): 53-80.

Casey, Anthony J. Posner, Eric A. 2015. "A Framework for Bailout Regulation." Notre Dame Law Review, 91: 479.

Chari, V. V., and Patrick J. Kehoe. 2016. "Bailouts, Time Inconsistency, and Optimal Regulation: A Macroeconomic View." American Economic Review, 106(9): 2458-2493.

Clayton, Christopher, and Andreas Schaab. 2020. "Bail-Ins, Optimal Regulation, and Crisis Resolution." Harvard University Working Paper.

Core, John E., Robert W. Holthausen, and David F. Larcker. 1999. "Corporate governance, Chief Executive Officer Compensation, and Firm Performance." Journal of Financial Economics, 51(3): 371-406.

Dam, Lammertjan, and Michael Koetter. 2012. "Bank Bailouts and Moral Hazard: Evidence from Germany." Review of Financial Studies, 25(8): 2343-2380.

Diamond, Douglas W., and Raghuram G. Rajan. 2002. "Bank Bailouts and Aggregate Liquidity." American Economic Review, 92(2): 38-41.

Duchin, Ran, and Denis Sosyura. 2014. "Safer Ratios, Riskier Portfolios: Banks' Response to Government Aid." Journal of Financial Economics, 113(1): 1-28.

Dávila, Eduardo, and Ansgar Walther. 2020. "Does Size Matter? Bailouts with Large and Small Banks." Journal of Financial Economics, 136(1): 1-22.

Engelberg, Joseph, Pengjie Gao, and Christopher A. Parsons. 2013. "The Price of a CEO's Rolodex." Review of Financial Studies, 26(1): 79-114.

Farhi, Emmanuel, and Jean Tirole. 2012. "Collective Moral Hazard, Maturity Mismatch, and Systemic Bailouts." American Economic Review, 102(1): 60-93.

Fracassi, Cesare, and Geoffrey Tate. 2012. "External Networking and Internal Firm Governance." Journal of Finance, 67(1): 153-194.

Geithner, Timothy F. 2014. Stress test: Reflections on financial crises. Crown Publishing Group $(\mathrm{NY})$.

Gormley, Todd A., and David A. Matsa. 2016. "Playing it safe? Managerial Preferences, Risk, and Agency Conflicts." Journal of Financial Economics, 122(3): 431-455.

Greenwood, Robin, Samuel Hanson, Jeremy C. Stein, and Adi Sunderam. 2017. "Strengthening and Streamlining Bank Capital Regulation." Brookings Papers on Economic Ac- 
tivity, 48(2 (Fall)): 479-565.

Huang, Sheng, Johan Maharjan, and Anjan V. Thakor. 2020. "Disagreement-Induced CEO Turnover." Journal of Financial Intermediation, 43: 100819.

Keister, Todd. 2016. "Bailouts and Financial Fragility." Review of Economic Studies, 83(2): 704736.

Klein, April. 2002. "Audit committee, board of director characteristics, and earnings management." Journal of Accounting and Economics, 33(3): 375-400.

Lee, David S., and Thomas Lemieux. 2010. "Regression Discontinuity Designs in Economics." Journal of Economic Literature, 48(2): 281-355.

Mace, Myles L. 1971. Directors: Myth and Reality. Harvard Business School Press.

Macey, Jonathan R, and Maureen O’Hara. 2016. "Bank corporate governance: a proposal for the post-crisis world." Economic Policy Review, Issue Aug, 85-105.

Mehran, Hamid, Alan D. Morrison, and Joel D. Shapiro. 2011. "Corporate Governance and Banks: What Have We Learned from the Financial Crisis?" 502.

Merton, Robert C. 1977. "An Analytic Derivation of the Cost of Deposit Insurance and Loan Guarantees: An Application of Modern Option Pricing Theory." Journal of Banking \& Finance, 1(1): 3-11.

Philippon, Thomas, and Oliver Wang. 2021. "Let the Worst One Fail: A Credible Solution to the Too-Big-To-Fail Conundrum."

Philippon, Thomas, and Philipp Schnabl. 2013. "Efficient Recapitalization." Journal of Finance, 68(1): 1-42.

Philippon, Thomas, and Vasiliki Skreta. 2012. "Optimal Interventions in Markets with Adverse Selection." American Economic Review, 102(1): 1-28.

Silver-Greenberg, Jessica, and Susanne Craig. 2012. "Citi Chairman Is Said to Have Planned Chief's Exit Over Months." The New York Times, October 25.

Thakor, Anjan V. 2018a. "Post-crisis Regulatory Reform in Banking: Address Insolvency Risk, Not illiquidity!" Journal of Financial Stability, 37: 107-111.

Thakor, Anjan V. 2018b. The Purpose of Banking: Transforming Banking For Stability and Economic growth. New York:Oxford University Press.

Tirole, Jean. 2012. "Overcoming Adverse Selection: How Public Intervention Can Restore Market 
Functioning." American Economic Review, 102(1): 29-59.

Wilson, Linus, and Yan Wendy Wu. 2012. "Escaping TARP." Journal of Financial Stability, 8(1): $32-42$. 


\section{$6 \quad$ Figures}

Figure 1

\section{A Numerical Example}

Figure 1 shows values for $1-e_{n}^{*}$, the probability of missing a dividend payment conditional on having missed $n$ payments, as implied by the model presented in Section 3.1. Parameter values are the following: $k=6, B=5, \beta=0.5, N^{*}=6$.

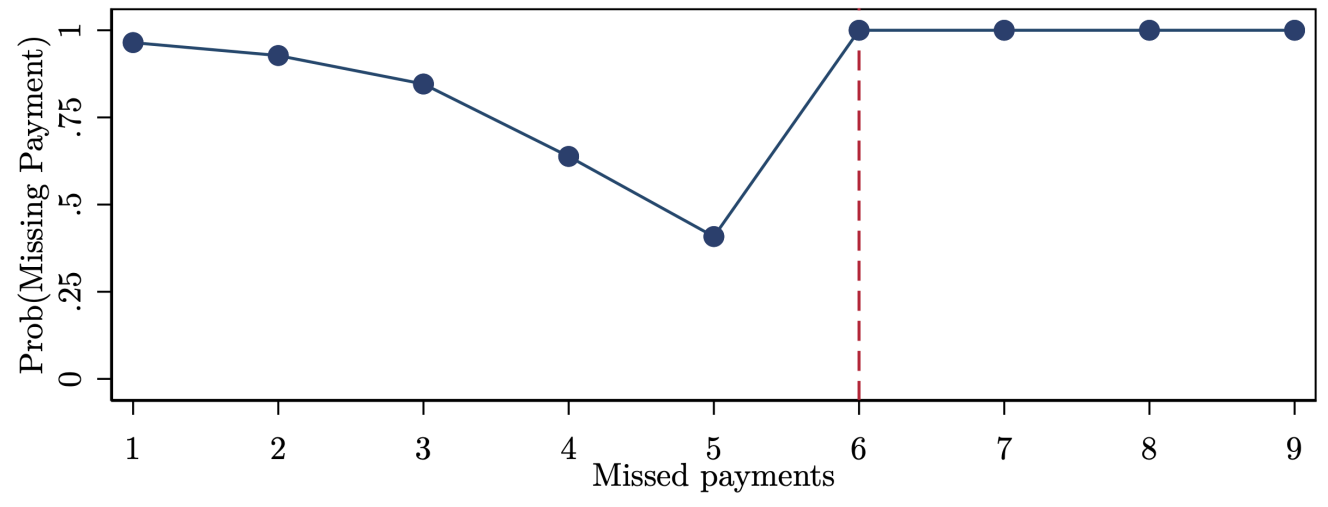

Figure 2

Distribution of Missed Dividend Payments

Figure 2 plots the distribution of missed dividend payments for 2,082 bank-quarter observations. Banks having 0 missed payments are excluded, leaving 193 banks that missed at least one dividend payment out of the 569 banks in the sample. The time coverage goes from May 2009 to October 2019.

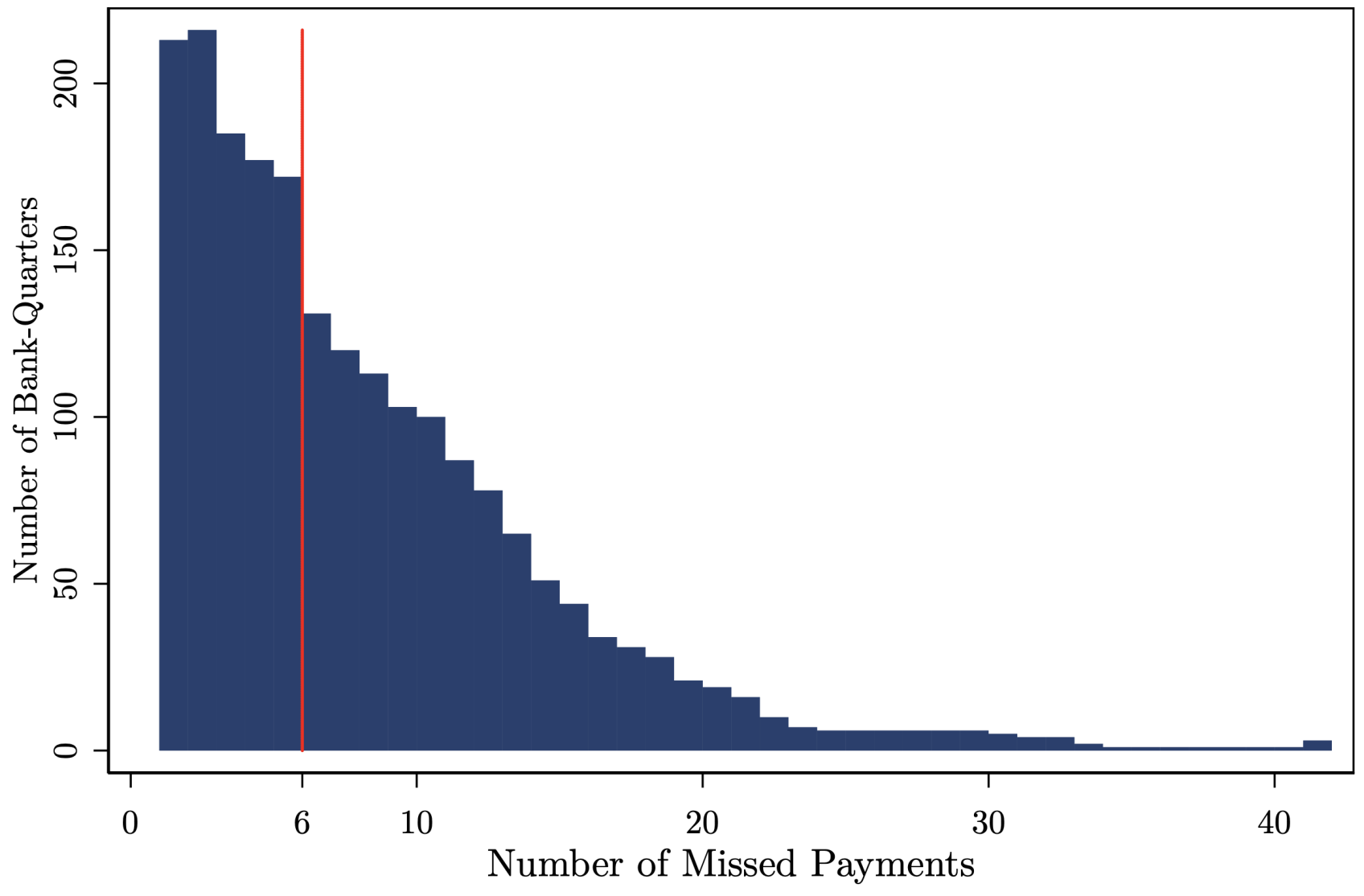


Figure 3

Conditional Distribution of

Changes in Missed Dividend Payments

Figure 3 shows the average quarter-to-quarter change in the number of missed dividend payments for the 193 banks with $1,2, \ldots, 10$, and more than 10 missed dividend payments at the end of the previous quarter. Observations for banks having 0 missed payments at the end of the previous quarter are excluded. The time coverage goes from May 2009 to October 2019.

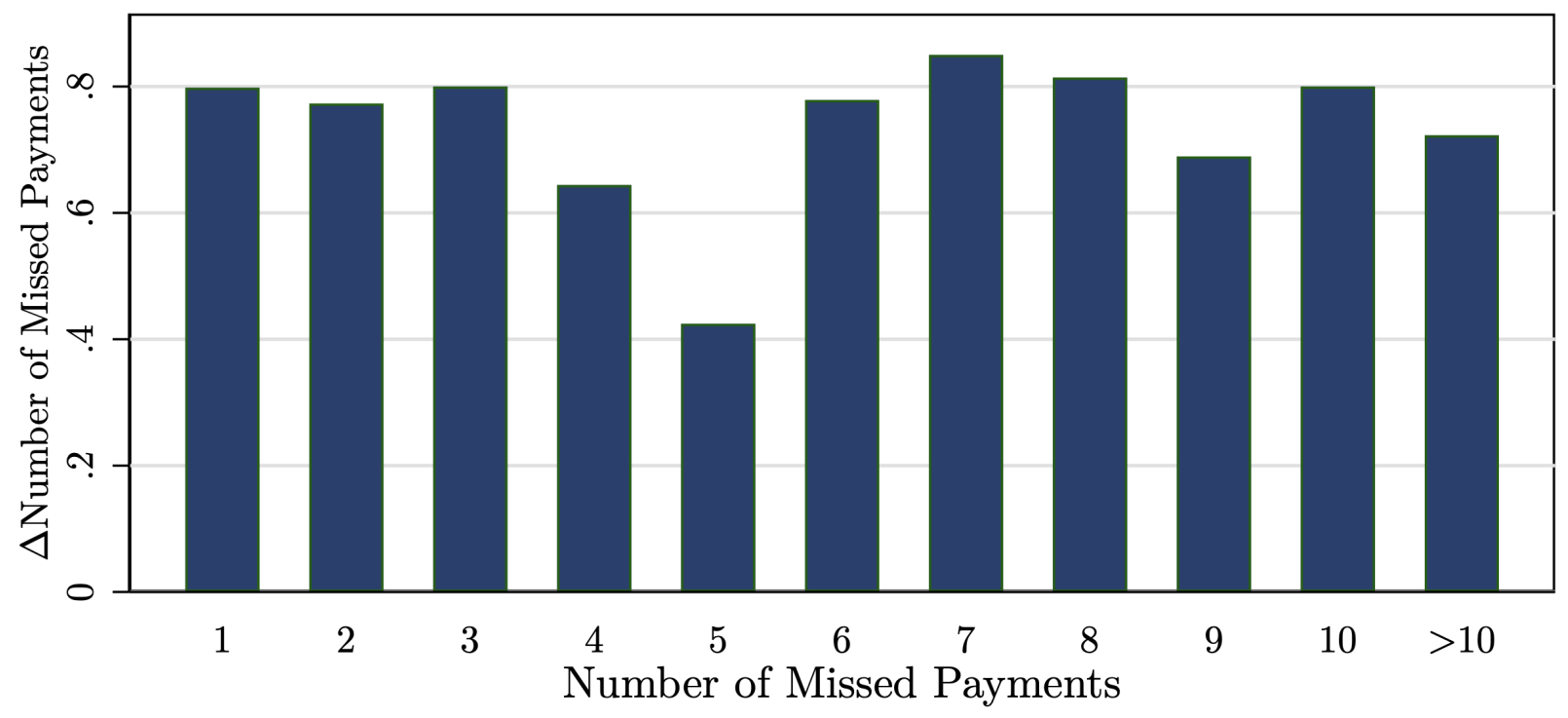

Figure 4

Missed Payments: Plot of OLS Coefficients

Figure 4 shows OLS coefficients and corresponding $95 \%$ confidence intervals obtained after regressing the quarter-to-quarter change in the number of missed dividend payments on dummies corresponding to the number of missed dividend payments. The sample consists of 569 banks, and the time coverage goes from May 2009 to October 2019. The value corresponding to the number $n$ on the $x$-axis represents the coefficient estimated on a dummy equal to 1 if the bank has $n$ outstanding missed dividend payments. The coefficient corresponding to $n=5$ is omitted. Banks with more than 10 missed dividend payments are binned together, and the coefficient on the corresponding dummy is the rightmost one. Standard errors are clustered at the bank level.

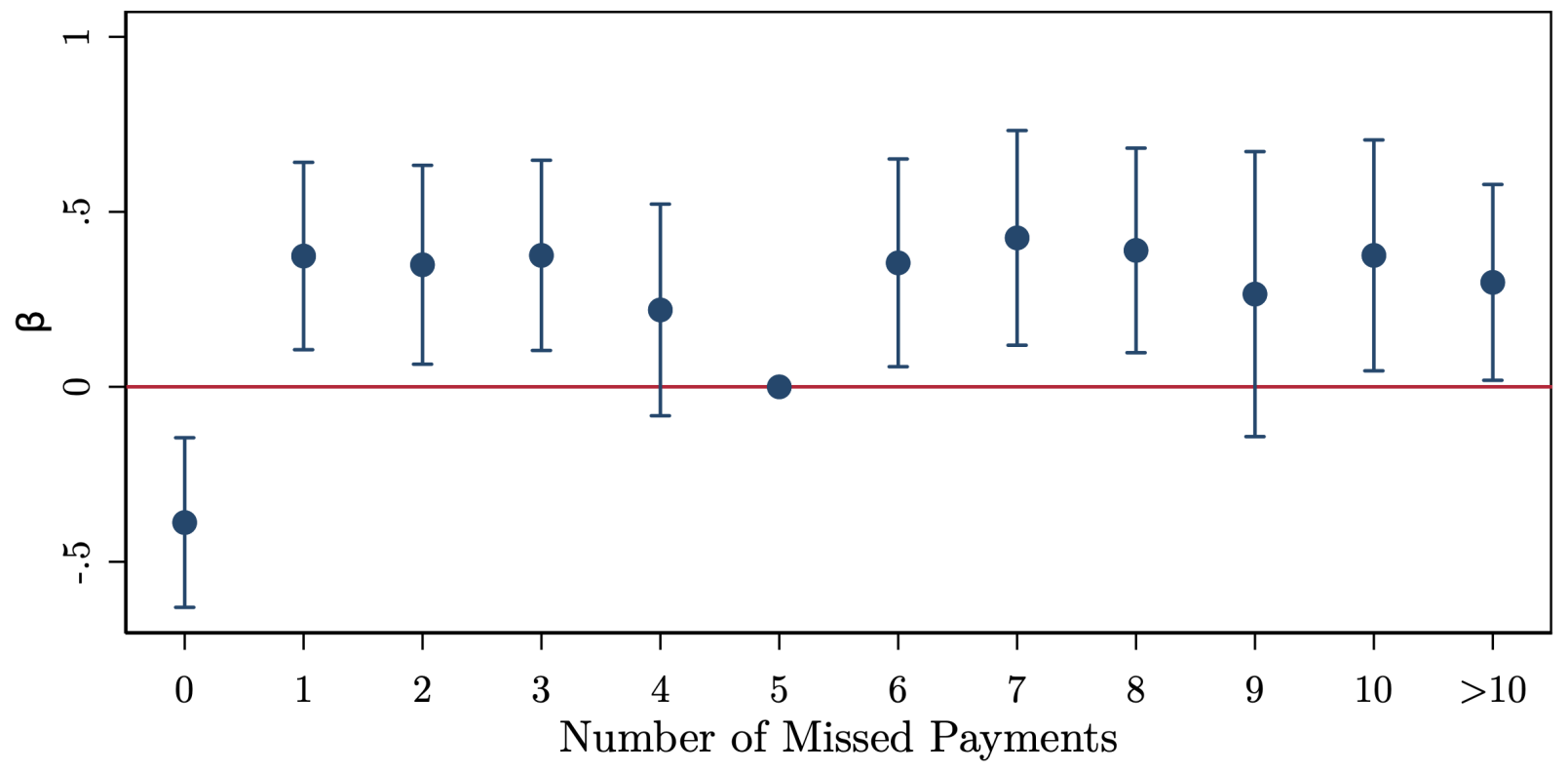




\section{Figure 5}

\section{Event-Study Evidence}

Panels A, B, C, and D of Figure 5 present the coefficients with their corresponding $95 \%$ confidence intervals from event-study regressions. A bank is "treated" if, at any point in time, it had a Treasury-appointed director. Every treated bank is matched with up to 4 control banks, matched on $\log$ (revenues), leverage ratio, loans-to-deposits ratio, and a listed dummy. The dependent variable is regressed on firm and year fixed effects, a vector of dummies corresponding to the difference between the event-year and the year of the observation, and the interaction of this vector with a "treated" dummy. The plots report the coefficients on these interaction terms. Standard errors are clustered at the bank-level. The dependent variables are NPLs/Loans (Panel A), ROA (Panel B), ROE (Panel C), and abnormal accruals (Panel D). NPLs/Loans represents nonaccrual and restructured loans as a percent of total loans and leases. ROA represents net income over average total assets in percentage points. ROE represents net income over average total equity in percentage points. Abnormal accruals correspond to the abnormal loss provision and are computed following Beatty, Ke and Petroni (2002).

Panel A. NPLs/Loans

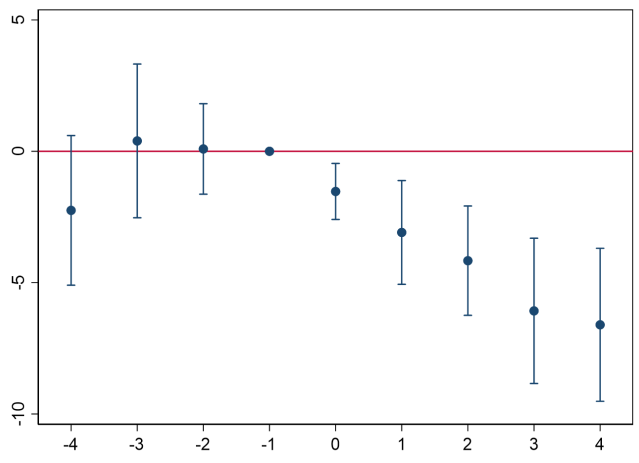

Panel C. ROE

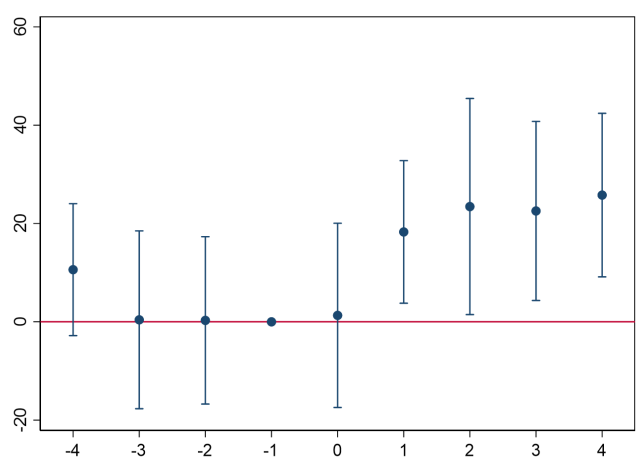

Panel B. ROA

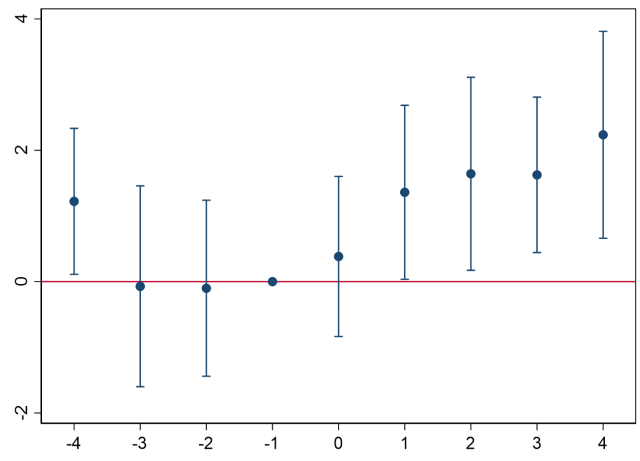

Panel C. Abnormal Accruals

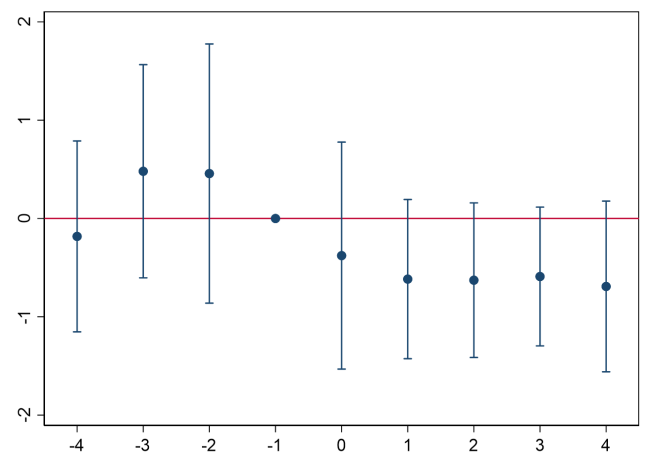


Figure 6

The "Pandit Shock": Number of Banks in the CPP

Table 6 shows the number of banks whose shares have not been auctioned and which did not transition to the Small Business Lending Fund that are still in the $\mathrm{CPP}$ at the end of each quarter. The figure displays the total number of banks (in green), the total number of banks eligible for a director appointment (in blue) and the total number of banks non-eligible for a director appointment (in red) between the last quarter of 2010 and the third quarter of 2013.

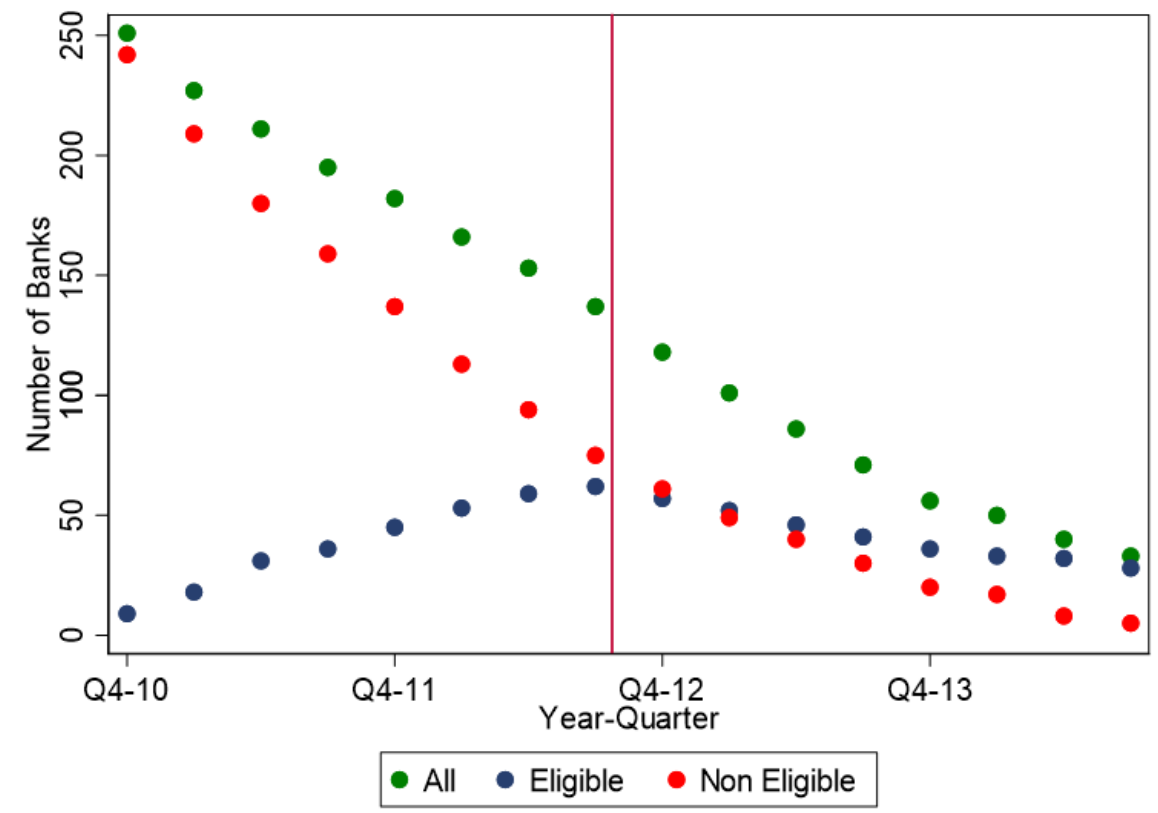

Figure 7

The "Pandit Shock": Exits from CPP

Figure 7 displays the number of bank exits from the CPP for each quarter between the last quarter of 2010 and the third quarter of 2013. The sample includes 157 exiting banks whose shares have not been auctioned and which did not transition to the Small Business Lending Fund. The red line plots the exits from banks that are not eligible for a director appointment; the blue line plots the exits from banks that are eligible for a director appointment.

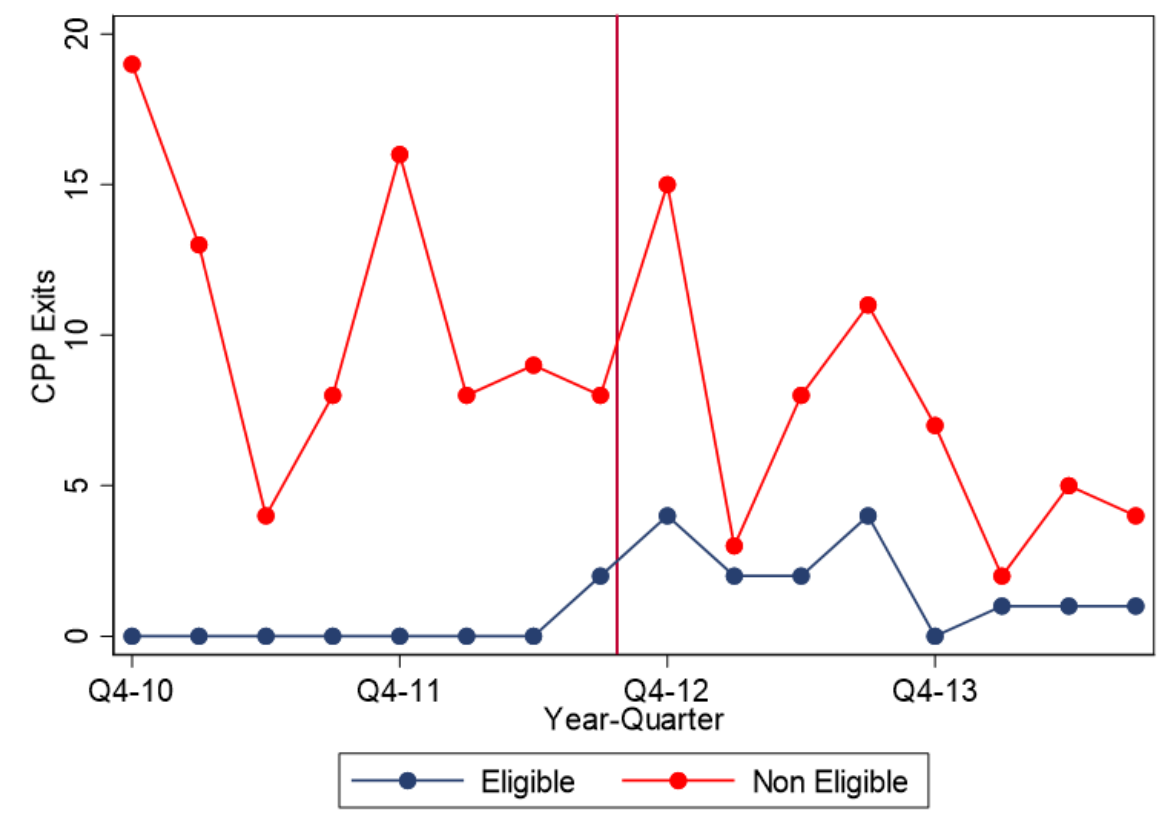




\section{Tables}

Table 1

\section{Descriptive Statistics}

Table 1 has descriptive statistics (number of observations, mean, median, standard deviation, first, and 99 percentile) for the main variables used in the paper. Panel A includes all 569 banks in the sample covering May 2009 to October 2019. Panel B only includes observations for the 193 banks that missed at least one dividend payment. Number of missed payments is the number of missed dividend payments at the end of the quarter. $\Delta$ Missed payments is the quarter-to-quarter change in missed dividend payments. Log(revenues) is the logarithm of the sum of net interest income, noninterest income, and gains on sales of securities. Leverage ratio is defined as the Tier 1 capital as a percentage of adjusted average assets. Risk-based capital ratio represents total regulatory capital as a percent of risk-adjusted assets in percentage points. Tier 1 capital ratio represents core capital (Tier 1) as a percent of risk-adjusted assets. Listed is an indicator variable for the company being publicly listed. ROA represents net income over average total assets in percentage points. ROE represents net income over average total equity in percentage points. NPLs/Loans is defined as nonaccrual and restructured loans as a percent of total loans and leases.

Panel A. Full Sample

\begin{tabular}{lrrrrrr}
\hline & Obs. & Mean & Median & St. Dev. & Perc. 1 & Perc. 99 \\
\hline Number of Missed Payments & 6,808 & 2.38 & 0.00 & 5.03 & 0.00 & 22.00 \\
$\Delta$ Missed Payments & 6,808 & 0.25 & 0.00 & 0.75 & 0.00 & 1.00 \\
Log(Revenues) & 6,808 & 8.62 & 8.47 & 1.47 & 5.92 & 13.37 \\
Leverage Ratio & 6,808 & 9.15 & 9.21 & 2.77 & 2.03 & 15.82 \\
Risk-Based Capital Ratio & 6,808 & 14.10 & 13.77 & 3.97 & 4.93 & 26.08 \\
Tier 1 Risk-based Ratio & 6,808 & 12.57 & 12.29 & 3.98 & 2.99 & 24.54 \\
Loans/Deposits & 6,808 & 85.43 & 85.78 & 21.75 & 48.23 & 123.39 \\
Listed & 6,808 & 0.46 & 0.00 & 0.50 & 0.00 & 1.00 \\
ROA & 6,808 & -0.24 & 0.28 & 2.32 & -10.05 & 2.80 \\
ROE & 6,786 & -5.01 & 3.10 & 37.96 & -160.37 & 37.14 \\
NPLs/Loans & 6,808 & 5.36 & 4.22 & 4.35 & 0.02 & 20.34 \\
\hline
\end{tabular}

Panel B. Banks with at least 1 Missed Payment

\begin{tabular}{lrrrrrr}
\hline & Obs. & Mean & Median & St. Dev. & Perc. 1 & Perc. 99 \\
\hline Number of Missed Payments & 2,082 & 7.79 & 6.00 & 6.38 & 1.00 & 30.00 \\
$\Delta$ Missed Payments & 2,082 & 0.73 & 1.00 & 1.20 & -5.00 & 1.00 \\
Log(Revenues) & 2,082 & 8.25 & 8.17 & 1.17 & 5.68 & 11.52 \\
Leverage Ratio & 2,082 & 7.70 & 7.90 & 3.47 & 0.15 & 16.47 \\
Risk-Based Capital Ratio & 2,082 & 12.68 & 12.56 & 5.00 & 0.43 & 29.62 \\
Tier 1 Risk-based Ratio & 2,082 & 11.11 & 11.13 & 5.04 & 0.22 & 28.25 \\
Loans/Deposits & 2,082 & 80.25 & 79.78 & 26.31 & 47.46 & 120.16 \\
Listed & 2,082 & 0.37 & 0.00 & 0.48 & 0.00 & 1.00 \\
ROA & 2,082 & -0.83 & 0.01 & 2.79 & -12.94 & 2.73 \\
ROE & 2,062 & -16.14 & 0.15 & 57.77 & -243.47 & 63.72 \\
NPLs/Loans & 2,082 & 8.37 & 7.32 & 5.44 & 0.20 & 23.76 \\
\hline
\end{tabular}


Table 2

\section{Baseline Results}

Table 2 presents regressions where the dependent variable is the change in the number of missed dividend payments between quarter $t$ and quarter $t-1$. The sample contains the 569 banks covering May 2009 to October 2019. Missed Payments $=n$ is a dummy equal to 1 if the bank has missed $n$ payments at the end of quarter $t-1$; Missed Payments $>10$ is a dummy equal to 1 if the bank has missed more than 10 payments at the end of quarter $t-1$. Columns 2 through 4 control for quarter fixed effects. Column 3 also controls for Log(revenues) and the leverage ratio. Column 4 also includes ROA, NPLs/Loans, risk-based capital ratio, tier 1 capital ratio, and Listed as control variables. Log(revenues) is the logarithm of the sum of net interest income, noninterest income, and gains on sales of securities. Leverage ratio is defined as the tier 1 capital as a percent of adjusted average assets. ROA represents net income over average total assets in percentage points. NPLs/Loans is defined as nonaccrual and restructured loans as a percent of total loans and leases. Risk-based capital ratio represents total regulatory capital as a percent of risk-adjusted assets in percentage points. Tier 1 capital ratio represents core capital (Tier 1 ) as a percent of risk-adjusted assets. Listed is an indicator variable for the company being publicly listed. The control variables are measured at the end of quarter $t-1$. Standard errors, in parentheses, are clustered at the bank level. $* * *, * *$, and * indicate statistically different from zero at the $1 \%, 5 \%$, and $10 \%$ level of significance, respectively.

\begin{tabular}{|c|c|c|c|c|}
\hline & (1) & (2) & (3) & (4) \\
\hline Missed Payments $=0$ & $\begin{array}{l}-0.388^{* * *} \\
(0.123)\end{array}$ & $\begin{array}{l}-0.401^{* * *} \\
(0.121)\end{array}$ & $\begin{array}{l}-0.344^{* * *} \\
(0.120)\end{array}$ & $\begin{array}{l}-0.268^{* *} \\
(0.119)\end{array}$ \\
\hline Missed Payments $=1$ & $\begin{array}{l}0.374^{* * *} \\
(0.136)\end{array}$ & $\begin{array}{l}0.358^{* * *} \\
(0.135)\end{array}$ & $\begin{array}{l}0.373^{* * *} \\
(0.132)\end{array}$ & $\begin{array}{l}0.378^{* * *} \\
(0.130)\end{array}$ \\
\hline Missed Payments $=2$ & $\begin{array}{l}0.349^{* *} \\
(0.145)\end{array}$ & $\begin{array}{l}0.336^{* *} \\
(0.143)\end{array}$ & $\begin{array}{l}0.354^{* *} \\
(0.140)\end{array}$ & $\begin{array}{l}0.368^{* * *} \\
(0.134)\end{array}$ \\
\hline Missed Payments $=3$ & $\begin{array}{l}0.376^{* * * *} \\
(0.138)\end{array}$ & $\begin{array}{l}0.360^{\text {**** }} \\
(0.136)\end{array}$ & $\begin{array}{l}0.359^{* * *} \\
(0.134)\end{array}$ & $\begin{array}{l}0.361^{* * *} \\
(0.131)\end{array}$ \\
\hline Missed Payments $=4$ & $\begin{array}{c}0.220 \\
(0.154)\end{array}$ & $\begin{array}{c}0.205 \\
(0.152)\end{array}$ & $\begin{array}{c}0.204 \\
(0.150)\end{array}$ & $\begin{array}{c}0.205 \\
(0.147)\end{array}$ \\
\hline Missed Payments $=6$ & $\begin{array}{c}0.354^{* *} \\
(0.151)\end{array}$ & $\begin{array}{l}0.358^{* *} \\
(0.151)\end{array}$ & $\begin{array}{c}0.344^{* *} \\
(0.149)\end{array}$ & $\begin{array}{c}0.335^{* *} \\
(0.146)\end{array}$ \\
\hline Missed Payments $=7$ & $\begin{array}{l}0.426^{* * *} \\
(0.156)\end{array}$ & $\begin{array}{l}0.430^{* * *} \\
(0.156)\end{array}$ & $\begin{array}{l}0.420^{* * *} \\
(0.154)\end{array}$ & $\begin{array}{l}0.406^{* * *} \\
(0.152)\end{array}$ \\
\hline Missed Payments $=8$ & $\begin{array}{l}0.390^{* * *} \\
(0.149)\end{array}$ & $\begin{array}{l}0.383^{* * *} \\
(0.147)\end{array}$ & $\begin{array}{c}0.370^{* *} \\
(0.145)\end{array}$ & $\begin{array}{c}0.358^{* *} \\
(0.143)\end{array}$ \\
\hline Missed Payments $=9$ & $\begin{array}{c}0.265 \\
(0.207)\end{array}$ & $\begin{array}{c}0.261 \\
(0.211)\end{array}$ & $\begin{array}{c}0.243 \\
(0.209)\end{array}$ & $\begin{array}{c}0.232 \\
(0.207)\end{array}$ \\
\hline Missed Payments $=10$ & $\begin{array}{c}0.376^{* *} \\
(0.168)\end{array}$ & $\begin{array}{c}0.381^{* *} \\
(0.167)\end{array}$ & $\begin{array}{c}0.370^{* *} \\
(0.165)\end{array}$ & $\begin{array}{c}0.365^{* *} \\
(0.163)\end{array}$ \\
\hline Missed Payments $>10$ & $\begin{array}{l}0.298^{* *} \\
(0.142)\end{array}$ & $\begin{array}{l}0.358^{* *} \\
(0.146)\end{array}$ & $\begin{array}{l}0.331^{* *} \\
(0.144)\end{array}$ & $\begin{array}{c}0.320^{* *} \\
(0.143)\end{array}$ \\
\hline Log(Revenues) & & & $\begin{array}{l}-0.016^{* * *} \\
(0.005)\end{array}$ & $\begin{array}{l}-0.038^{* *} \\
(0.018)\end{array}$ \\
\hline Leverage Ratio & & & $\begin{array}{l}-0.025^{* * *} \\
(0.006)\end{array}$ & $\begin{array}{l}-0.005 \\
(0.007)\end{array}$ \\
\hline ROA & & & & $\begin{array}{l}-0.011^{* * *} \\
(0.003)\end{array}$ \\
\hline NPLs/Loans & & & & $\begin{array}{l}0.016^{\text {*** }} \\
(0.003)\end{array}$ \\
\hline Risk-Based Capital Ratio & & & & $\begin{array}{c}0.002 \\
(0.013)\end{array}$ \\
\hline Tier 1 Risk-based Ratio & & & & $\begin{array}{l}-0.013 \\
(0.014)\end{array}$ \\
\hline Listed & & & & $\begin{array}{l}-0.019 \\
(0.019)\end{array}$ \\
\hline Log(Total Funds) & & & & $\begin{array}{c}0.019 \\
(0.019)\end{array}$ \\
\hline Observations & 6,808 & 6,808 & 6,808 & 6,808 \\
\hline $\mathrm{R}^{2}$ & 0.186 & 0.216 & 0.225 & 0.234 \\
\hline Year-Quarter FE & & $\mathrm{X}$ & $\mathrm{X}$ & $\mathrm{X}$ \\
\hline
\end{tabular}


Table 3

\section{Polynomial Approximation}

Table 3 presents regressions where the dependent variable is the change in the number of missed dividend payments between quarter $t$ and quarter $t-1$. The sample consists of 569 banks, and the time coverage goes from May 2009 to October 2019. Missed payments $\geq 6$ is a dummy equal to 1 if the bank has missed at least 6 dividend payments by the end of the previous quarter. The regressions also include two first-order (columns 1 and 3 ) and second-order (columns 2 and 4) polynomials on the number of missed payments minus 6 , separately estimated for banks below and above the six-missed-payments cutoff, interacted with the Missed Payments $\geq 6$ dummy. Columns 3 and 4 also include the following control variables: $\log$ (revenues), leverage ratio, ROA, NPLs/Loans, risk-based capital ratio, Listed, and year-quarter fixed effects. $\log$ (revenues) is the logarithm of the sum of net interest income, noninterest income, and gains on sales of securities. Leverage ratio is defined as tier 1 capital as a percentage of adjusted average assets. ROA is net income over average total assets in percentage points. NPLs/Loans is defined as nonaccrual and restructured loans as a percentage of total loans and leases. Risk-based capital ratio is total regulatory capital as a percentage of risk-adjusted assets. Tier 1 capital ratio is core capital (Tier 1) as a percentage of risk-adjusted assets. Listed is an indicator variable for the company being publicly listed. The control variables are measured at the end of quarter $t-1$. Standard errors, in parentheses, are clustered at the bank level. ***, **, and $*$ indicate statistically different from zero at the $1 \%, 5 \%$, and $10 \%$ level of significance, respectively.

\begin{tabular}{lcccc}
\hline & $(1)$ & $(2)$ & $(3)$ & $(4)$ \\
\hline Missed Payments $\geq 6$ & $0.367^{* * *}$ & $0.666^{* * *}$ & $0.427^{* * *}$ & $0.683^{* * *}$ \\
& $(0.132)$ & $(0.245)$ & $(0.126)$ & $(0.229)$ \\
Observations & 1,617 & 1,617 & 1,464 & 1,464 \\
$\mathrm{R}^{2}$ & 0.010 & 0.012 & 0.081 & 0.083 \\
\hline Degree of Polynomial & 1 & 2 & 1 & 2 \\
Controls & & & $\mathrm{X}$ & $\mathrm{X}$ \\
\hline
\end{tabular}


Table 4

T-Tests

Table 4 presents $t$-tests computed under the null hypothesis that the means of the variables listed are equal for treated and control banks. The sample includes 56 banks. Each of the 12 banks receiving a Treasury-appointed director ("treated") is matched with at most four banks that have the closest propensity score ("control"), using the variables Log(revenues), leverage ratio, loans/deposits, and Listed as predictors of the director appointment (shown in Panel A). A maximum difference of 0.025 in the propensity scores is required. Panels $\mathrm{B}$ and $\mathrm{C}$ display analogous $t$-tests for the outcome variables and for additional, selected variables. $\log$ (revenues) is defined as the logarithm of the sum of net interest income, noninterest income, and gains on sales of securities. The leverage ratio is the tier 1 capital as a percentage of adjusted average assets. Loans/deposits is defined as the ratio of total loans and leases (net of unearned income and gross of reserve) divided by total deposits. Listed is an indicator variable for the company being publicly listed. NPLs/loans is nonaccrual and restructured loans as a percentage of total loans and leases. ROA is defined as net income over average total assets in percentage points. ROE is net income over average total equity in percentage points. Risk-based capital ratio is defined as total regulatory capital as a percent of risk-adjusted assets in percentage points. Abnormal accruals are defined as abnormal loss provisions and are computed following Beatty, Ke and Petroni (2002). Log(assets) is the logarithm of total assets. Retained earnings/assets is defined as the net value of undivided profits and capital reserves as a percentage of total assets. Cash/assets is given by cash and equivalents as a percent of total assets. Log(total funds) is the logarithm of the total dollar amount funded through the CPP. The matching variables are measured at the beginning of the appointment year. The first and second column report means for the four variables for treated and control banks, respectively. The third column reports the difference between the two means. The fourth column reports the $p$-value computed under the null hypothesis that the means are equal.

Panel A. Matched Variables

\begin{tabular}{lcccc}
\hline Variable & $\begin{array}{c}\text { Mean } \\
\text { Treated }\end{array}$ & $\begin{array}{c}\text { Mean } \\
\text { Control }\end{array}$ & $\begin{array}{c}\text { Treated }- \\
\text { Control }\end{array}$ & p-value \\
\hline Log(Revenues) & 10.770 & 10.686 & 0.084 & 0.815 \\
Leverage Ratio (\%) & 7.308 & 8.158 & -0.849 & 0.423 \\
Loans/ Deposits (\%) & 74.283 & 76.061 & -1.777 & 0.667 \\
Listed & 0.667 & 0.682 & -0.015 & 0.923 \\
\hline
\end{tabular}

Panel B. Outcome Variables

\begin{tabular}{lcccc}
\hline Variable & $\begin{array}{c}\text { Mean } \\
\text { Treated }\end{array}$ & $\begin{array}{c}\text { Mean } \\
\text { Control }\end{array}$ & $\begin{array}{c}\text { Treated }- \\
\text { Control }\end{array}$ & p-value \\
\hline NPLs/Loans & 7.525 & 5.333 & 2.192 & 0.147 \\
ROA & -0.604 & 0.239 & -0.843 & 0.154 \\
ROE & -13.352 & 0.168 & -13.519 & 0.209 \\
Risk-Based Capital Ratio & 12.799 & 13.907 & -1.108 & 0.421 \\
Tier 1 Risk-based Ratio & 10.560 & 12.200 & -1.640 & 0.267 \\
Abnormal Accruals & 0.288 & -0.063 & 0.351 & 0.291 \\
\hline
\end{tabular}

Panel C. Additional Variables

\begin{tabular}{lcccc}
\hline Variable & $\begin{array}{c}\text { Mean } \\
\text { Treated }\end{array}$ & $\begin{array}{c}\text { Mean } \\
\text { Control }\end{array}$ & $\begin{array}{c}\text { Treated }- \\
\text { Control }\end{array}$ & p-value \\
\hline Ret. Earnings/Assets & -3.010 & 0.027 & -3.036 & 0.179 \\
Log(Assets) & 13.971 & 13.920 & 0.051 & 0.882 \\
Cash/Assets & 7.389 & 8.505 & -1.116 & 0.529 \\
Log(Total Funds) & 17.399 & 16.855 & 0.544 & 0.110 \\
\hline
\end{tabular}


Table 5

Difference-in-Difference Results

Table 5 presents difference-in-difference regressions where the dependent variable is indicated on the top of each column. The sample contains 56 banks. Treated is a dummy equal to 1 if a bank had a Treasury-appointed director, and 0 otherwise. Every treated bank is matched with up to 4 control banks, matched on Log(revenues), leverage ratio, loans-to-deposits ratio, and a listed dummy. For treated banks, Post is a dummy equal to 1 in the year of the director appointment and in the following years. For control banks, it is a dummy equal to 1 in the year in which the matched treated bank has received a director appointment and in the following years. NPLs/loans is defined as nonaccrual and restructured loans as a percentage of total loans and leases. ROA is defined as net income over average total assets in percentage points. ROE is net income over average total equity in percentage points. Risk-based capital ratio is defined as total regulatory capital as a percentage of risk-adjusted assets. Tier 1 capital ratio is core capital (Tier 1) as a percentage of risk-adjusted assets. Abnormal accruals are defined as abnormal loss provisions and are computed following Beatty, Ke and Petroni (2002). All the regressions include year and firm fixed effects. Standard errors, in parentheses, are clustered at the bank level. ***, **, and * indicate statistically different from zero at the $1 \%, 5 \%$, and $10 \%$ level of significance, respectively.

\begin{tabular}{lcccccc}
\hline Dependent Variable: & NPLs/Loans & ROA & ROE & $\begin{array}{c}\text { Risk-Based } \\
\text { C.R. }\end{array}$ & Tier 1 C.R. & $\begin{array}{c}\text { Abnormal } \\
\text { Accruals }\end{array}$ \\
\cline { 2 - 7 } & $(1)$ & $(2)$ & $(3)$ & $(4)$ & $(5)$ & $(6)$ \\
\hline Post $\times$ Treated & $-3.437^{* * *}$ & $1.075^{* * *}$ & $14.020^{* * *}$ & 0.320 & -0.040 & $-0.751^{* * *}$ \\
& $(0.570)$ & $(0.309)$ & $(3.665)$ & $(0.695)$ & $(0.800)$ & $(0.200)$ \\
Post & 0.340 & 0.254 & 0.528 & 0.402 & 0.875 & -0.170 \\
& $(0.609)$ & $(0.283)$ & $(3.848)$ & $(0.626)$ & $(0.596)$ & $(0.283)$ \\
Observations & 466 & 466 & 462 & 466 & 466 & 425 \\
$\mathrm{R}^{2}$ & 0.716 & 0.525 & 0.496 & 0.592 & 0.599 & 0.443 \\
\hline Year FE & $\mathrm{X}$ & $\mathrm{X}$ & $\mathrm{X}$ & $\mathrm{X}$ & $\mathrm{X}$ & $\mathrm{X}$ \\
Firm FE & $\mathrm{X}$ & $\mathrm{X}$ & $\mathrm{X}$ & $\mathrm{X}$ & $\mathrm{X}$ & $\mathrm{X}$ \\
\hline
\end{tabular}

\section{Table 6}

CEO Turnover and Compensation

Table 6 presents difference/in/difference regressions where the dependent variables are either a CEO turnover dummy (column 1) or the logarithm of CEO total compensation (columns 2 through 6). Treated is a dummy equal to 1 if a bank had a Treasuryappointed director, and 0 otherwise. Every treated bank is matched with up to 4 control banks, matched on Log(revenues), leverage ratio, loans-to-deposits ratio, and a listed dummy. For treated banks, Post is a dummy equal in the year of the director appointment and in the following years. For control banks, it is a dummy equal to 1 in the year in which the matched treated bank has received a director appointment and in the following years. CPP is a dummy equal to 1 if the bank is in the CPP. ROA is defined as net income over average total assets in percentage points. ROE is net income over average total equity in percentage points. All the regressions include year and firm fixed effects. Standard errors, in parentheses, are clustered at the bank level. ${ }^{* *},{ }^{* *}$, and $*$ indicate statistically different from zero at the $1 \%, 5 \%$, and $10 \%$ level of significance, respectively.

\begin{tabular}{|c|c|c|c|c|c|c|}
\hline \multirow{2}{*}{ Dependent Variable: } & \multirow{2}{*}{$\begin{array}{c}\text { Turnover } \\
(1)\end{array}$} & \multicolumn{5}{|c|}{$\log ($ Compensation $)$} \\
\hline & & (2) & (3) & (4) & (5) & (6) \\
\hline Post $\times$ Treated & $\begin{array}{l}-0.014 \\
(0.056)\end{array}$ & $\begin{array}{l}-0.286^{* *} \\
(0.130)\end{array}$ & $\begin{array}{l}-0.256^{* *} \\
(0.125)\end{array}$ & $\begin{array}{l}-0.337^{* *} \\
(0.126)\end{array}$ & $\begin{array}{l}-0.346^{* *} \\
(0.129)\end{array}$ & $\begin{array}{l}-0.376^{* * *} \\
(0.133)\end{array}$ \\
\hline Post & $\begin{array}{c}0.040 \\
(0.083)\end{array}$ & $\begin{array}{c}0.122 \\
(0.154)\end{array}$ & $\begin{array}{c}0.125 \\
(0.153)\end{array}$ & $\begin{array}{c}0.103 \\
(0.158)\end{array}$ & $\begin{array}{c}0.136 \\
(0.177)\end{array}$ & $\begin{array}{c}0.148 \\
(0.176)\end{array}$ \\
\hline CPP & & & $\begin{array}{l}-0.141^{*} \\
(0.080)\end{array}$ & & & \\
\hline ROA & & & & $\begin{array}{l}0.045^{* *} \\
(0.021)\end{array}$ & & $\begin{array}{c}0.069 \\
(0.085)\end{array}$ \\
\hline ROE & & & & & $\begin{array}{l}0.004^{* *} \\
(0.002)\end{array}$ & $\begin{array}{l}-0.001 \\
(0.006)\end{array}$ \\
\hline Observations & 444 & 258 & 258 & 258 & 254 & 254 \\
\hline $\mathrm{R}^{2}$ & 0.116 & 0.903 & 0.904 & 0.905 & 0.907 & 0.907 \\
\hline Year FE & $\mathrm{X}$ & $\mathrm{X}$ & $\mathrm{X}$ & $\mathrm{X}$ & $\mathrm{X}$ & $\mathrm{X}$ \\
\hline Firm FE & $\mathrm{X}$ & $\mathrm{X}$ & $\mathrm{X}$ & $\mathrm{X}$ & $\mathrm{X}$ & $\mathrm{X}$ \\
\hline
\end{tabular}


Table 7

Predicted Probability of Treasury Appointment

Table 7 presents probit estimates of director appointments by the Treasury. The dependent variable is an indicator variable being 1 for banks where a director has been appointed by the Treasury and 0 otherwise. The sample is a cross-section of the banks at the time they become eligible for board director appointments, i.e., when they missed six dividend payments. Log(revenues) is defined as the logarithm of the sum of net interest income, noninterest income, and gains on sales of securities. Leverage ratio is defined as the tier 1 capital as a percentage of adjusted average assets. Loans/deposits is the ratio of total loans and leases (net of unearned income and gross of reserve) divided by total deposits. Listed is an indicator variable for the company being publicly listed. Funds $>\$ 25$ million is an indicator variable for receiving investment by the Treasury larger than $\$ 25$ Million. NPLs/loans is defined as nonaccrual and restructured loans as a percentage of total loans and leases. ROA is defined as net income over average total assets in percentage points. ROE is net income over average total equity in percentage points. Retained earnings/assets is defined as net value of undivided profits and capital reserves as a percentage of total assets. Cash/assets is given by cash and equivalents as a percentage of total assets. Risk-based capital ratio is defined as total regulatory capital as a percentage of risk-adjusted assets. The control variables are measured at the end of the quarter of missing six payments the first time. Heteroscedasticity-consistent standard errors are reported in parentheses. $* * *, * *$, and * indicate statistically different from zero at the $1 \%, 5 \%$, and $10 \%$ level of significance, respectively.

\begin{tabular}{|c|c|c|c|}
\hline & $(1)$ & $(2)$ & $(3)$ \\
\hline Log(Revenues $)$ & $\begin{array}{l}0.694^{* * *} \\
(0.171)\end{array}$ & $\begin{array}{c}0.546^{* *} \\
(0.233)\end{array}$ & $\begin{array}{l}0.680^{* * *} \\
(0.255)\end{array}$ \\
\hline Leverage Ratio & $\begin{array}{c}0.023 \\
(0.046)\end{array}$ & $\begin{array}{c}0.033 \\
(0.046)\end{array}$ & $\begin{array}{c}0.012 \\
(0.167)\end{array}$ \\
\hline Loans/Deposits & $\begin{array}{l}-0.020 \\
(0.013)\end{array}$ & $\begin{array}{l}-0.021 \\
(0.014)\end{array}$ & $\begin{array}{l}-0.041^{* *} \\
(0.017)\end{array}$ \\
\hline Listed & $\begin{array}{c}0.182 \\
(0.358)\end{array}$ & $\begin{array}{c}0.130 \\
(0.348)\end{array}$ & $\begin{array}{c}0.247 \\
(0.424)\end{array}$ \\
\hline Funds $>25$ million & & $\begin{array}{c}0.417 \\
(0.531)\end{array}$ & $\begin{array}{c}0.441 \\
(0.614)\end{array}$ \\
\hline NPLs/Loans & & & $\begin{array}{c}0.008 \\
(0.045)\end{array}$ \\
\hline $\mathrm{ROA}$ & & & $\begin{array}{l}-0.241 \\
(0.186)\end{array}$ \\
\hline $\mathrm{ROE}$ & & & $\begin{array}{c}0.010 \\
(0.011)\end{array}$ \\
\hline Ret. Earnings/Assets & & & $\begin{array}{l}0.091^{* *} \\
(0.045)\end{array}$ \\
\hline Cash/Assets & & & $\begin{array}{l}-0.041 \\
(0.034)\end{array}$ \\
\hline Risk-Based Capital Ratio & & & $\begin{array}{l}-0.090 \\
(0.127)\end{array}$ \\
\hline Observations & 122 & 122 & 119 \\
\hline Pseudo $\mathrm{R}^{2}$ & 0.296 & 0.304 & 0.419 \\
\hline AUROC & $\begin{array}{c}0.893 \\
(0.030)\end{array}$ & $\begin{array}{c}0.889 \\
(0.034)\end{array}$ & $\begin{array}{c}0.914 \\
(0.030)\end{array}$ \\
\hline Year FE & $\mathrm{X}$ & $\mathrm{X}$ & $\mathrm{X}$ \\
\hline
\end{tabular}


Table 8

The "Pandit Shock": Difference-in-Difference Analysis

Table 8 presents the average number of exits per quarter by splitting observations according to whether banks are eligible for a director appointment and whether an exit occurs before the fourth quarter of 2012. The sample includes 157 bank exits. The last column reports the difference between the first two columns, and the last row reports the difference between the first two rows. The cell at the bottom right corner of the table reports the "difference-in-difference" estimate. Heteroscedasticity-consistent standard errors are reported in parentheses.

\begin{tabular}{lccc}
\hline & Before & After & After - Before \\
\cline { 2 - 4 } Not Eligible & 10.625 & 6.875 & -3.750 \\
& $(1.752)$ & $(1.552)$ & $(2.340)$ \\
Eligible & 0.250 & 1.875 & 1.625 \\
& $(0.250)$ & $(0.515)$ & $(0.573)$ \\
Eligible - Not Eligible & -10.375 & -5.000 & $\mathbf{5 . 3 7 5}$ \\
& $(1.770)$ & $(1.635)$ & $\mathbf{( 2 . 4 1 0 )}$ \\
\hline
\end{tabular}




\section{For Online Publication}

\section{Appendices}

We now present additional institutional details and results omitted from the main text for brevity. Appendix A1 proves Proposition 1 in the main text (see Section 3.1). Appendix A2 describes the various recapitalization programs included in TARP, and provides a detailed summary of the provisions of the CPP in Table A1. Appendix A3 has a list of all the appointments made by the Treasury for each bank, with dates and director names. When available, the table also reports the committees the directors were part of at the time of the appointments.

Appendix A4 has additional empirical results. Figure A1 is a bar chart of the funds invested by the Treasury in the banks participating in the CPP in million dollars. Each bar's width is $\$ 0.1$ million. For clarity, we truncate the distribution at $\$ 50$ million. Figure $A 2$ plots the distribution of the year-quarters in which each bank has reached five missed dividend payments for the first time.

In Figure $A 3$ we fit the relationship between the outstanding number of missed dividend payments and the change to the next quarter by estimating equation (eq:polynomial) in the main text, using linear (Panel A) and quadratic (Panel B) polynomials. Figure A4 presents event-study evidence on the effect board appointments made by the Treasury on the risk-based capital ratio and the tier 1 capital ratio (see Sections 4.2 and 4.3 for details).

Table A3 presents a regression where the dependent variable is the change in the number of missed dividend payments between two quarters and the independent variables are several predictors, included either as standalone variables or all together (column 11). In this test only banks with five missed payments are included.

In Table A4, we show results along the lines of those presented in Section 4.3 (Table 5), using different procedures to select the control group for the banks eventually subject to a director appointment. In Panel A, we employ exactly the same matching procedure described in Section 4.2 but now use as potential control banks the entire universe of regulated financial institutions in SNL. As a result, the number of banks we are able to match increases, and our sample size ranges between 579 and 595, depending on the availability of the dependent variable. Panel A of Table A4 shows results that are quantitatively and qualitatively similar to those presented in the main text. For NPLs/loans, ROA, and ROE, if anything, the point estimates of the key coefficient of interest are slightly larger in magnitude.

In Panel B, for every bank receiving an appointment by the Treasury, the control group is restricted only to institutions that are also eligible for director appointments. Given the decision of the Treasury to prioritize for the appointment of directors banks receiving at least $\$ 25$ million in funding amount (see Section 2.1), we match treated and control banks also based on a dummy equal to 1 for banks crossing this cutoff, and zero otherwise. This approach has the advantage of being the most conservative one. However, it also dramatically reduces the pool of potential control banks and, as a result, the statistical power of the tests. To increase the sample size, we include only size among the continuous variables we match on, and increase the maximum difference in the propensity scores to 0.05 . Despite the substantial drop in sample size, which now ranges between 193 and 211 observations, we find results that are consistent with those in the main text. The coefficients in Columns 2 and 3, where we analyze the effects on ROA and ROE, are statistically significant and, if anything, larger than those found in the baseline tests. Only the effect on NPLs/Loans

(Column 1) ceases to be statistically significant, even if the coefficient on the Post $\times$ Treated term remains 
economically large in magnitude.

Appendix A5 presents additional evidence on the stock market reaction to Treasury's director appointments. Figure A5 plots buy-and-hold net returns for 1, 2,.., 12 months following the appointment month, computed using the market model.

Table A5 presents regressions where the dependent variable is the bank's stock return at different horizons. In columns 1 through 4 , the dependent variable is the cumulative abnormal return over a three-day window surrounding the announcement of the appointment of a director by the Treasury through an 8-K filing. In columns 5 through 8 , the dependent variable is the 12-month buy-and-hold return, measured starting from the month following the appointment. The regressor of interest is a "treated" dummy equal to 1 for banks receiving a director appointment. The sample includes 21 banks (or 20, depending on data availability) at the intersection between the sample of 56 banks defined in Section of the main text and the Center for Research in Security Prices (CRSP) database. We could not obtain 8-K filings for three banks; thus, the regressions in columns 1 through 4 have only 18 observations. All the regressions control for "match" fixed effects, i.e., a vector of dummies corresponding to each treated-matched bank combination. When indicated, control variables include the logarithm of market capitalization, the book to market ratio, and the lagged 12-month buy-and-hold return. Stock returns are adjusted using the market model in columns 1, 3, 5, and 7 and in the other columns using the Fama-French 3-factor model. We compute factor loadings using up to 36 monthly stock return observations prior to the appointment month. The factors have been downloaded from Kenneth French's website ${ }^{31}$.

\section{Appendix A1 Proof of Proposition 1}

Let $V_{n}$ the value function of a bank with $n$ missed payments. Clearly, for $n \geq N^{*}$ the bank manager has no incentive to pay dividends, nor she can enjoy the private benefit; hence, $e_{n}^{*}=V_{n}^{*}=0$ for all $n \geq N^{*}$. Now consider the problem of a manager that has missed $N^{*}-1$ dividend payments. The value function can be written as:

$$
V_{N^{*}-1}=e \beta\left(V_{N^{*}-1}+B\right)-k \frac{e^{2}}{2}
$$

The first-order condition implies:

$$
\frac{\partial V_{N^{*}-1}}{\partial e}=0 \Leftrightarrow e=\frac{\beta\left(V_{N^{*}-1}+B\right)}{k}
$$

By plugging expression A2 into A1, we obtain:

$$
V_{N^{*}-1}^{*}=\frac{k-\sqrt{k} \sqrt{k-4 \beta^{2} B}}{2 \beta^{2}}-B
$$

and

$$
e_{N^{*}-1}^{*}=\frac{k-\sqrt{k} \sqrt{k-4 \beta^{2} B}}{2 k \beta} .
$$

This value is a positive real number, as ensured by the assumption that $k>4 \beta^{2} B$, and is lower than 1 , as ensured by the assumption that $k>\beta B /(1-\beta)$. Equation (A1) also has a second root that, under the assumption that $k>\beta B /(1-\beta)$, implies that $e_{N^{*}-1}^{*}>1$. Hence, the only economically sensible value for

31. See https://mba.tuck.dartmouth.edu/pages/faculty/ken.french/data_library.html. 
$e_{N^{*}-1}^{*}$ is the one in equation (A4).

Now consider a generic period $n<N^{*}-1$. The value function can be written as:

$$
V_{n}=B+e \beta V_{n}+(1-e) \beta V_{n+1}^{*}-k \frac{e^{2}}{2}
$$

The first-order conditions implies:

$$
\frac{\partial V_{n}}{\partial e}=0 \Leftrightarrow e=\frac{\beta\left(V_{n}-V_{n+1}^{*}\right)}{k}
$$

Plugging (A6) into (A5), and after some algebra, we obtain:

$$
V_{n}^{*}=V_{n+1}^{*}+\frac{k-\sqrt{k} \sqrt{2 V_{n+1}^{*}(1-\beta) \beta^{2}+k-2 \beta^{2} B}}{\beta^{2}}
$$

Notice that $V_{n+1}^{*} \geq 0$. To see that, notice that the manager could simply set $e^{*}=0$ forever and achieve 0 utility. This observation, together with the assumption that $k>4 \beta^{2} B$, ensures that the rightmost term under the square root is positive and, hence, the solution is well-defined.

Also, notice that $V_{n+1}^{*}<B /(1-\beta)$. To see that, notice that $V_{n+1}^{*}=B /(1-\beta)$ is the value function of a manager that obtains the private benefit in every period with probability 1 but has an effort cost equal to 0 , which is not achievable. Simple algebra shows that this upper bound on $V_{n+1}^{*}$ implies that the ratio in equation A5 is strictly positive, which further implies that $V_{n}^{*}>V_{n+1}^{*}$. Hence, $V_{n}^{*}$ is decreasing in $n$.

We can plug expression A7 into equation A6 and find:

$$
e_{n}^{*}=\frac{k-\sqrt{k} \sqrt{2 V_{n+1}^{*}(1-\beta) \beta^{2}+k-2 \beta^{2} B}}{k \beta}
$$

The $B /(1-\beta)$ upper bound for $V_{n+1}^{*}$ ensures that $e_{n}^{*}>0$. Moreover, simple algebra shows that the assumption that $k>\beta B /(1-\beta)$ guarantees that $e_{n}^{*}<1$. As before, the alternative root of equation $\mathrm{A} 7$ implies a value for $e_{n}^{*}$ greater than 1 and can thus be discarded.

$e_{n}^{*}$ is decreasing in $V_{n+1}^{*}$, which is, in turn, decreasing in $n$. Hence, $e_{n}^{*}$ is increasing in $n$. The probability that the bank with $n$ missed payments will miss the next payment is given by $1-e_{n}^{*}$. Thus, this probability is decreasing in $n$.

The values of $e_{n}^{*}$ for $n<N^{*}-1$ in Figure 1 can be obtained starting from expression A1, plugging it into expression A7 to obtain the value of $e_{n}^{*}$ from equation A8, and so on for every $n$, recursively up until $n=1$. 


\section{Appendix A2 Bank Recapitalization in the Troubled Asset Relief Program}

After the financial crisis, the U.S. Treasury set up a series of recapitalization and stabilization programs for the U.S. economy under the Troubled Asset Relief Program (TARP). Within TARP, the programs that focused on recapitalizing banks were: the Capital Purchase Program (CPP), the Community Development Capital Initiative (CDCI), the Targeted Investment Program (TIP), and the Capital Assistance Program $(\mathrm{CAP})^{32}$.

TIP only funded Citigroup and Bank of America with a total of $\$ 40$ billion in December 2008, which they paid back in 2009. The CDCI, on the other hand, focused on small institutions and funded banks with a total of only $\$ 570$ million starting in 2010. The CPP was by far the largest and had a volume of around $\$ 205$ billion, funding a total of 707 banks $^{32}$. No funds were distributed under the CAP (see Calomiris and Khan (2015)). Table A1 presents a schematic summary of the provision of the CPP, using additional information from the Term Sheets available at the Treasury's website ${ }^{33}$.

32. See "Quarterly Report to Congress" from the Office of the Special Inspector General for the Troubled Assets Relief Program, October 26, 2010.

33. See:

https://home.treasury.gov/data/troubled-assets-relief-program/bank-investment-programs/cap/related-resources 
Table A1

Capital Purchase Program Summary

Table A1 summarizes the provisions of the Capital Purchase Program.

\begin{tabular}{lccc}
\hline Type of Security & Preferred shares & Preferred shares & Subordinated debt \\
\hline Payment Type & Cumulative & Non-Cumulative & Cumulative \\
Bank Type & $\begin{array}{c}\text { Bank holding company, } \\
\text { savings and loan holding } \\
\text { company, mutual holding } \\
\text { company subsidiary }\end{array}$ & $\begin{array}{c}\text { Insured depository } \\
\text { institution that is not } \\
\text { controlled by a company }\end{array}$ & $\begin{array}{c}\text { S-Corporation, Mutual } \\
\text { holding Company, Mutual } \\
\text { bank }\end{array}$ \\
\hline
\end{tabular}

Funding Amount $\quad$ Up to $3 \%$ of total risk-weighted assets, but maximum amount $\$ 25$ billion

Dividend Rate $\quad 5 \%$ (after 5 years $9 \%$ ) $\quad 5 \%$ (after 5 years $9 \%$ ) $\quad 7.7 \%$ (after 5 years $9 \%$ )

$\begin{array}{llll}\text { Participants } & 569 & 86 & 52\end{array}$

Missed payment

rules:

1 Missed Payment $\quad$ Common dividend payments prohibited until...

$\begin{array}{ccc}\text {...all missed preferred } & \text {...current preferred } \\ \text { dividends have been paid } & \text { dividend paid } & \text {...all missed interest } \\ \text { back } & \text { payments have been paid } \\ \text { back }\end{array}$

3 Missed Payments

Enhanced monitoring by Treasury ${ }^{\mathrm{b}}$

5 Missed Payments $\quad$ Treasury can ask for an observer to attend board meetings

6 Missed Payments $\quad$ Right to appoint of up to two board directors by Treasury until...

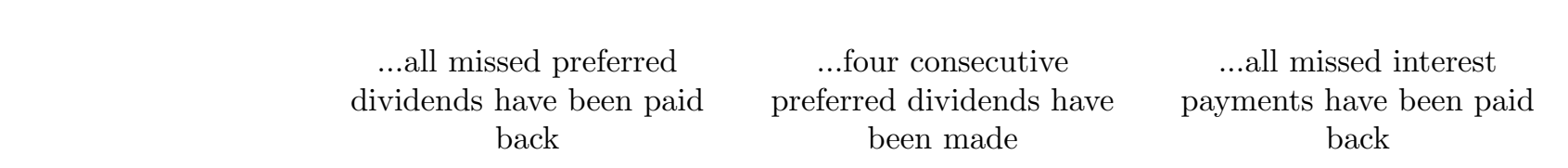

$\begin{aligned} & \text { Compensation } \\ & \text { restrictions }\end{aligned}$
golden parachutes restricted, bonus claw-backs requested, compensation tax
deductibility capped at $\$ 500,000$

(After February 2009, retention awards and bonuses prohibited, incentive compensation restricted ${ }^{\mathrm{a}}$, executive compensation capped at $\$ 500,000$ )

\section{Repayment}

Until 3 years of participation only through issuance of new equity

(After February 2009, restriction removed ${ }^{\mathrm{a}}$ )

\footnotetext{
a These provisions were implemented by the American Recovery and Reinvestment Act, which changed the provisions of the program retrospectively.

b These rules have been made announced after the start of the program (see "Quarterly Report to Congress" from the Office of the Special Inspector General for the Troubled Assets Relief Program, October 26, 2010).
} 


\section{Appendix A3 Director Appointment Events}

Table A2

\section{Dates of U.S. Treasury's Appointments and Directors' Names}

Table A2 lists appointment dates and names of directors appointed by the U.S. Treasury pursuant to missing six or more payments on CPP shares. The committee the director sat in the year of the appointment according to the proxy statement of the bank is shown in parenthesis after the name: Audit (A), Asset/Liability (A/L), Corporate Governance (CG), Compliance (CO), Compensation (CP), Loans (L), Risk (R), Funds Management (FM), and no information (n/a). The column Left? indicates when a director left the board, where "No" indicates the director was reported to be on the board at least one year after the exit from the CPP and "Yes" indicates that the director left the board before or within one year from the exit. We leave the cell blank whenever a bank leaves the program through a merger or a bankruptcy proceeding. The four banks at the bottom of the table are excluded from the analysis presented in Sections 4.3 and 4.4.

\begin{tabular}{|c|c|c|c|c|c|c|}
\hline Bank Name & $\begin{array}{c}\text { Date } 1^{\text {st }} \\
\text { Appointment }\end{array}$ & $1^{\text {st }}$ Director & Left? & $\begin{array}{c}\text { Date } 2^{\text {st }} \\
\text { Appointment }\end{array}$ & $2^{\text {st }}$ Director & Left? \\
\hline $\begin{array}{l}\text { Royal Bancshares of } \\
\text { Pennsylvania, Inc. }\end{array}$ & 2011-07-19 & $\begin{array}{l}\text { Gerard M. } \\
\text { Thomchick (CP) }\end{array}$ & No & 2011-09-30 & Wayne Huey, Jr., & No \\
\hline $\begin{array}{l}\text { Centrue Financial } \\
\text { Corporation }\end{array}$ & 2011-09-21 & $\begin{array}{l}\text { Richard "Chan" } \\
\text { Peterson }\end{array}$ & No & $2012-04-25$ & Dennis Battles & No \\
\hline $\begin{array}{l}\text { Citizens Republic } \\
\text { Bancorp, Inc. }\end{array}$ & 2011-09-21 & $\begin{array}{l}\text { William M. } \\
\text { Fenimore, Jr. (R) }\end{array}$ & & $2011-10-05$ & $\begin{array}{l}\text { Madeleine L. } \\
\text { Champion (A) }\end{array}$ & \\
\hline PremierWest Bancorp & $2011-12-20$ & $\begin{array}{l}\text { Mary Carryer (A, } \\
\text { FM) }\end{array}$ & & 2012-03-14 & $\begin{array}{l}\text { Bruce Currier (A, } \\
\text { FM) }\end{array}$ & \\
\hline First Security Group & $2012-02-09$ & $\begin{array}{l}\text { Robert Lane (A, } \\
\mathrm{CO}, \mathrm{A} / \mathrm{L}, \mathrm{L})\end{array}$ & No & $2012-03-22$ & $\begin{array}{l}\text { William Grant } \\
(\mathrm{A}, \mathrm{CO}, \mathrm{CP}, \mathrm{CG})\end{array}$ & No \\
\hline $\begin{array}{l}\text { Intervest Bancshares } \\
\text { Corporation }\end{array}$ & $2012-03-23$ & $\begin{array}{l}\text { Susan Roth } \\
\text { Katzke }\end{array}$ & No & $2012-10-24$ & C. Wayne Crowell & No \\
\hline $\begin{array}{l}\text { Bridgeview Bancorp, } \\
\text { Inc. }\end{array}$ & 2012-04-19 & James Kane (n/a) & No & & & \\
\hline $\begin{array}{l}\text { First Trust } \\
\text { Corporation }\end{array}$ & $2012-06-12$ & $\begin{array}{l}\text { Randall Howard } \\
\text { (n/a) }\end{array}$ & No & $2012-08-06$ & $\begin{array}{l}\text { Paul O'Connor } \\
\text { (n/a) }\end{array}$ & No \\
\hline Blue Valley Ban Corp & 2012-09-12 & James Gegg & No & & & \\
\hline $\begin{array}{l}\text { Citizens Bancshares } \\
\text { Co. }\end{array}$ & 2012-09-12 & James Gegg & No & & & \\
\hline $\begin{array}{l}\text { Old Second Bancorp, } \\
\text { Inc. }\end{array}$ & $2012-11-8$ & Duane Suits (A) & No & & & \\
\hline $\begin{array}{l}\text { Northern States } \\
\text { Financial Corporation }\end{array}$ & $2012-12-14$ & $\begin{array}{l}\text { P. David Kuhl } \\
\text { (A) }\end{array}$ & Yes & & & \\
\hline \multicolumn{7}{|l|}{ Not in Sample } \\
\hline First Banks, Inc. & 2011-07-19 & $\begin{array}{l}\text { John S. Poelker } \\
\text { (A) }\end{array}$ & No & 2011-07-19 & $\begin{array}{l}\text { Guy Rounsaville, } \\
\text { Jr. (CP) }\end{array}$ & No \\
\hline Anchor Bancorp & 2011-10-03 & Duane Morse (A) & Yes & $2011-10-03$ & Leonard Rush (A) & Yes \\
\hline $\begin{array}{l}\text { Rogers Bancshares, } \\
\text { Inc. }\end{array}$ & 2012-01-09 & $\begin{array}{l}\text { Larry Mingledorff } \\
(\mathrm{n} / \mathrm{a})\end{array}$ & & & & \\
\hline Central Bancorp, Inc. & $2014-02-06$ & $\begin{array}{l}\text { Larry Mingledorff } \\
\text { (n/a) }\end{array}$ & & $2014-02-06$ & $\begin{array}{l}\text { Paul Clabuesch } \\
\text { (n/a) }\end{array}$ & \\
\hline
\end{tabular}




\section{Appendix A4 Additional Results: Distribution of Funds and Attributes of Missed Dividend Payments}

\section{Figure A1}

Distribution of Funds Invested in the CPP Program

Figure A1 plots the distribution of funds invested (in \$million) in the CPP program for each bank. The distribution is truncated at $\$ 50$ million, and each bar's width is $\$ 0.1$ million.

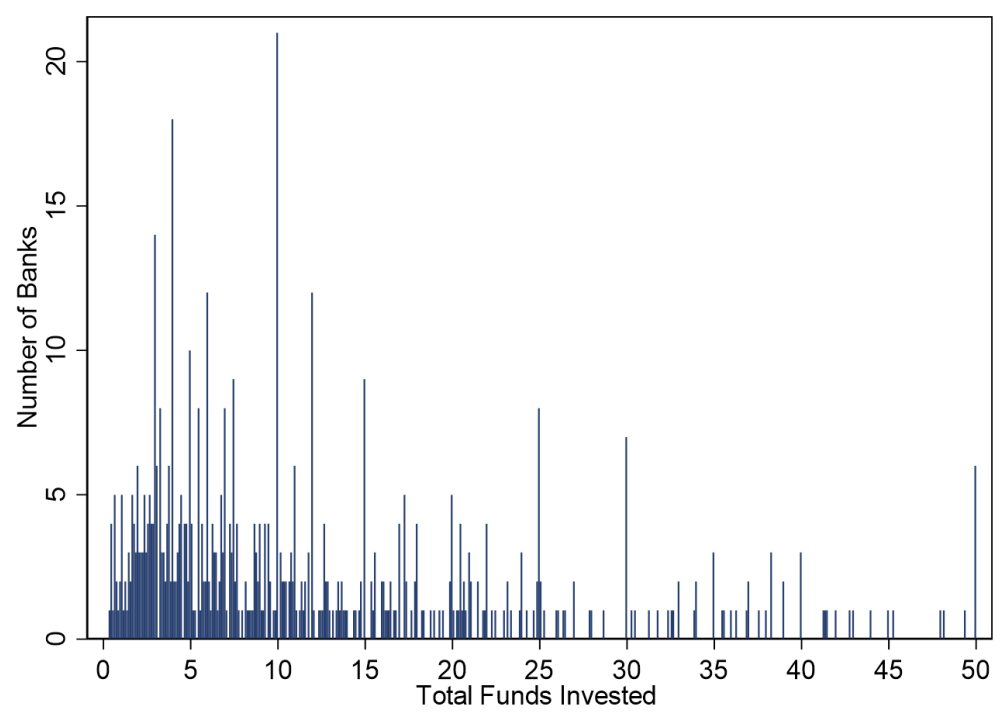

Figure A2

Timing of Missed Dividend Payments

Figure A2 plots the distribution of year-quarters in which each bank has reached five missed dividend payments for the first time.

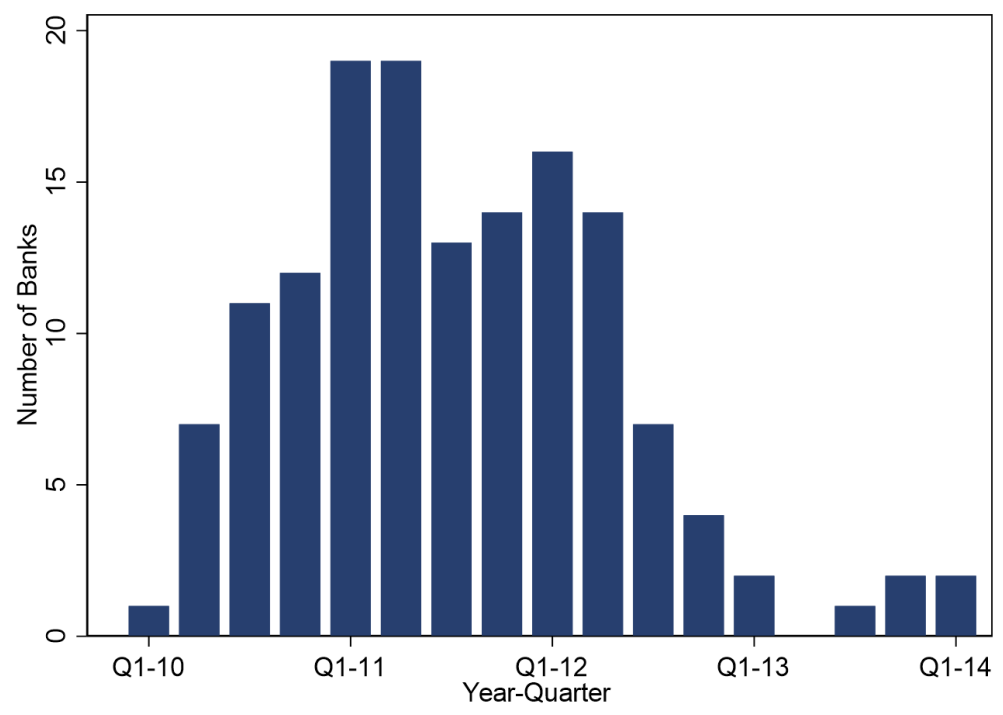


Figure A3

Change in Missed Payments: Polynomial Fits

Panels $\mathrm{A}$ and $\mathrm{B}$ of Figure 4 plot the quarter-to-quarter change in the number of missed dividend payments against the lagged number of missed payments. The sample consists of 569 banks, and the time coverage goes from May 2009 to October 2019. In Panels A and B, the blue lines fit linear and quadratic relationships, respectively, between the number of missed payments minus 6 and the change in missed payments, for banks with a number of missed payments between 1 and 5 (on the left) and between 6 and 11 (on the right).

Panel A. Linear Fit

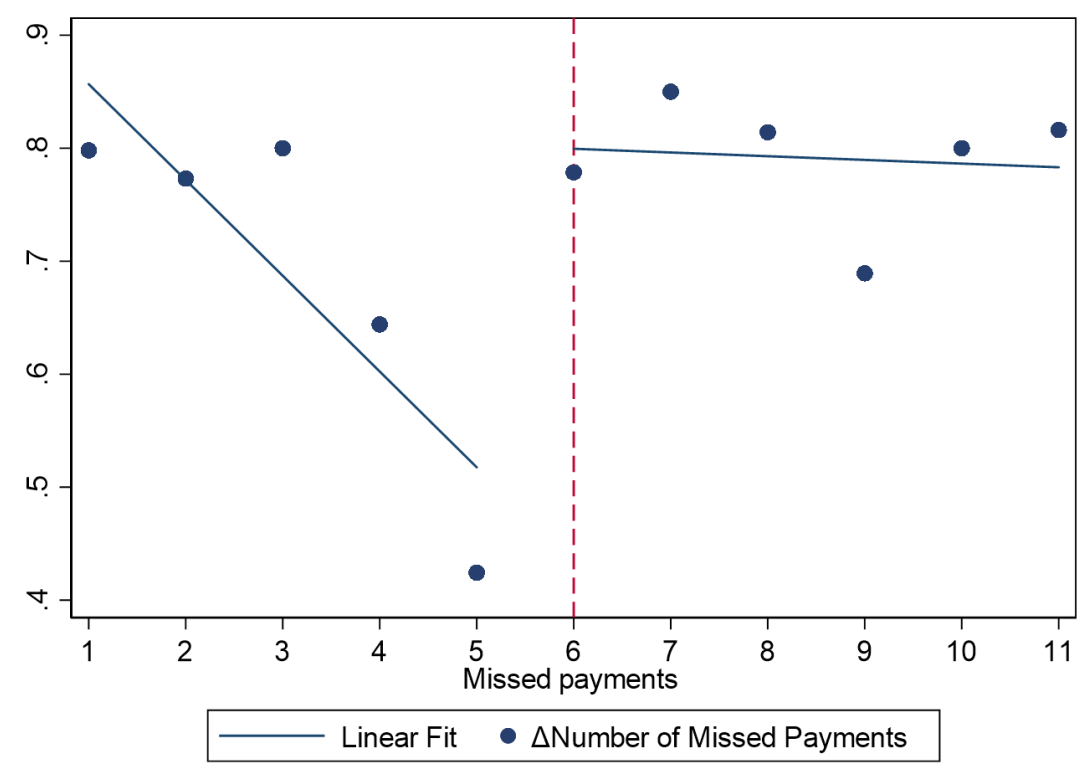

Panel B. Quadratic Fit

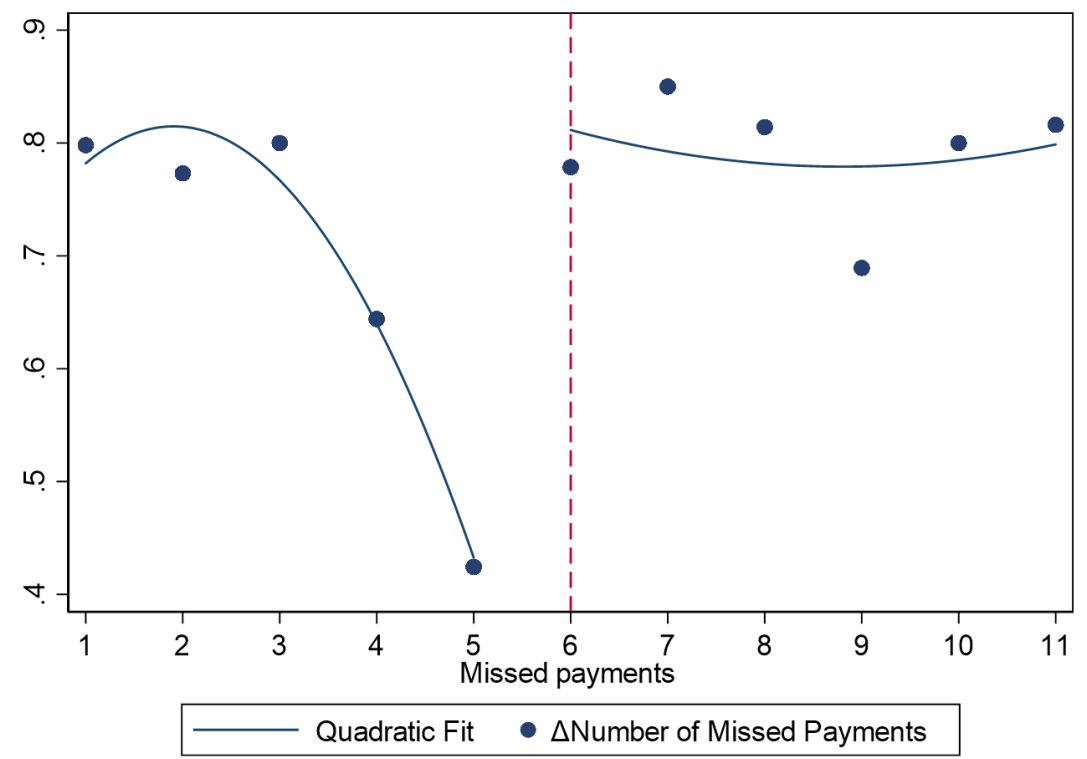




\section{Figure A4}

Event-Study Evidence:

\section{Risk-Based Capital Ratio and Tier 1 Capital Ratio}

Panels A and B of Figure A4 present coefficients with corresponding 95\% confidence intervals from event-study regressions. A bank is "treated" if, at any point in time, it had a Treasury-appointed director. Every treated bank is matched with up to 4 control banks, matched on $\log$ (revenues), leverage ratio, loans-to-deposits ratio, and a listed dummy. The dependent variable is regressed on firm fixed effects, a vector of dummies corresponding to the difference between the event-year and the year of the observation, and the interaction of this vector with a "treated" dummy. The plots report the coefficients on these interaction terms. Standard errors are clustered at the bank-level. The dependent variables are the risk-based capital ratio (Panel A) and the tier 1 capital ratio (Panel B). The risk-based capital ratio is defined as total regulatory capital as a percent of risk-adjusted assets. Tier 1 Capital Ratio represents core capital (Tier 1) as a percent of risk-adjusted assets.

\section{Panel A. Risk-Based Capital Ratio}

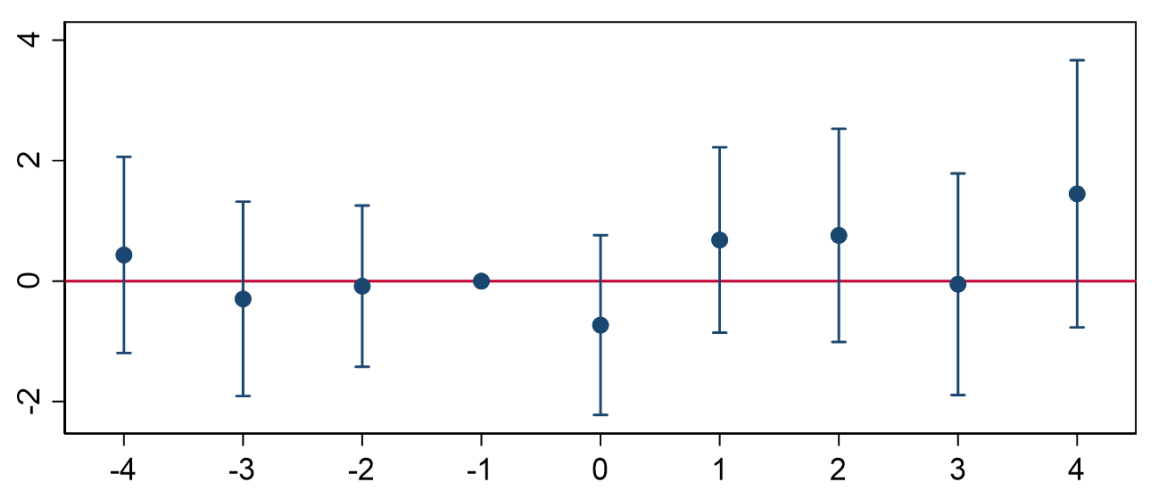

Panel B. Tier 1 Capital Ratio

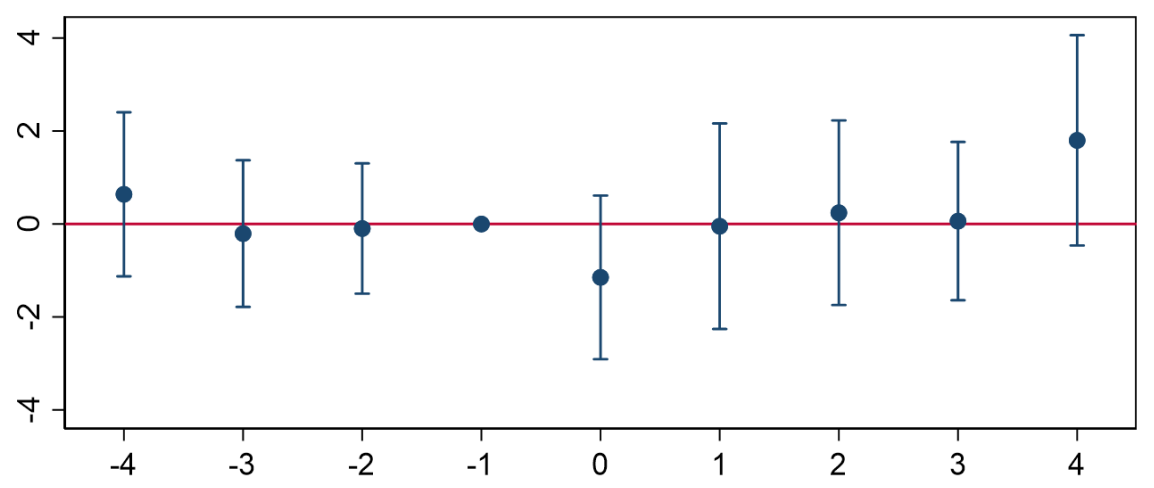




\section{Table A3}

\section{Predicting Changes in Missed Payments}

Table A3 presents regressions where the dependent variable is the change in the number of missed dividend payments between quarter $t$ and quarter $t-1$. The sample contains only banks with five missed dividend payments at the end of quarter $t-1$. All the tests control for year-quarter fixed effects. Log(revenues) represents the logarithm of the sum of net interest income, noninterest income, and gains on sales of securities. ROA is defined as net income over average total assets in percentage points. ROE is net income over average total equity in percentage points. NPLs/loans is nonaccrual and restructured loans as a percentage of total loans and leases. Leverage ratio represents the tier 1 capital as a percentage of adjusted average assets. Risk-based capital ratio represents total regulatory capital as a percentage of risk-adjusted assets. Z-score is defined as the sum of current tier 1 capital to assets ratio and average quarterly ROA, all divided by ROA's standard deviation (measured over the previous 12 quarters). Retained earnings/assets is the ratio of accumulated earnings that have been neither distributed to the shareholders nor apportioned for any specific purpose to total assets. Listed is an indicator variable for the company being publicly listed. $\log$ (total funds) is the logarithm of the total funding amount granted to each bank. The control variables are measured at the end of quarter $t-1$. Standard errors, in parentheses, are clustered at the bank level. ${ }^{* * *},{ }^{* *}$, and ${ }^{*}$ indicate statistically different from zero at the $1 \%, 5 \%$, and $10 \%$ level of significance, respectively.

\begin{tabular}{|c|c|c|c|c|c|c|c|c|c|c|c|}
\hline & (1) & $(2)$ & (3) & (4) & (5) & (6) & (7) & (8) & (9) & (10) & (11) \\
\hline Log(Revenues) & $\begin{array}{l}-0.185 \\
(0.133)\end{array}$ & & & & & & & & & & $\begin{array}{c}0.125 \\
(0.288)\end{array}$ \\
\hline ROA & & $\begin{array}{l}-0.098^{* *} \\
(0.044)\end{array}$ & & & & & & & & & $\begin{array}{l}-0.103 \\
(0.063)\end{array}$ \\
\hline $\mathrm{ROE}$ & & & $\begin{array}{l}-0.001 \\
(0.001)\end{array}$ & & & & & & & & $\begin{array}{c}0.003 \\
(0.002)\end{array}$ \\
\hline NPLs/Loans & & & & $\begin{array}{l}0.070^{* * *} \\
(0.026)\end{array}$ & & & & & & & $\begin{array}{l}0.072^{* *} \\
(0.026)\end{array}$ \\
\hline Leverage & & & & & $\begin{array}{l}-0.092^{* *} \\
(0.038)\end{array}$ & & & & & & $\begin{array}{l}-0.102 \\
(0.118)\end{array}$ \\
\hline Risk-Based C. R. & & & & & & $\begin{array}{l}-0.049^{* *} \\
(0.021)\end{array}$ & & & & & $\begin{array}{c}0.015 \\
(0.079)\end{array}$ \\
\hline Cash/Assets & & & & & & & $\begin{array}{l}0.010 \\
(0.014)\end{array}$ & & & & $\begin{array}{l}-0.012 \\
(0.016)\end{array}$ \\
\hline Ret. Earn./Assets & & & & & & & & $\begin{array}{l}-0.033^{* *} \\
(0.016)\end{array}$ & & & $\begin{array}{l}-0.016 \\
(0.020)\end{array}$ \\
\hline Listed & & & & & & & & & $\begin{array}{l}-0.309 \\
(0.270)\end{array}$ & & $\begin{array}{l}-0.175 \\
(0.275)\end{array}$ \\
\hline Log(Total Funds) & & & & & & & & & & $\begin{array}{l}-0.166 \\
(0.136)\end{array}$ & $\begin{array}{l}-0.389 \\
(0.306)\end{array}$ \\
\hline Observations & 168 & 168 & 166 & 168 & 168 & 168 & 168 & 168 & 168 & 168 & 166 \\
\hline $\mathrm{R}^{2}$ & 0.155 & 0.157 & 0.139 & 0.183 & 0.166 & 0.155 & 0.140 & 0.152 & 0.146 & 0.152 & 0.253 \\
\hline Year-Quarter FE & $\mathrm{X}$ & $\mathrm{X}$ & $\mathrm{X}$ & $\mathrm{X}$ & $\mathrm{X}$ & $\mathrm{X}$ & $\mathrm{X}$ & $\mathrm{X}$ & $\mathrm{X}$ & $\mathrm{X}$ & $\mathrm{X}$ \\
\hline
\end{tabular}


Table A4

Difference-in-Difference Results: Alternative Samples

Table 5 presents difference-in-difference regressions where the dependent variable is indicated on the top of each column. Treated is a dummy equal to 1 if a bank had a Treasury-appointed director, and 0 otherwise. Every treated bank is matched with up to 4 control banks. In Panel A, banks are matched based on $\log$ (revenues), leverage ratio, loans-to-deposits ratio, and a listed dummy. In Panel B, they are matched based on $\log$ (revenues), a listed dummy, and a dummy equal to 1 if the funding amount provided by the Treasury was higher than $\$ 25$ million. Panel A includes all the regulated institutions in the SNL database; Panel B includes only banks eligible for a director appointment. For treated banks, Post is a dummy equal to 1 in the year of the director appointment and in the following years. For control banks, it is a dummy equal to 1 after the matched treated bank has received a director appointment and 0 afterwards. NPLs/loans is defined as nonaccrual and restructured loans as a percentage of total loans and leases. ROA is defined as net income over average total assets in percentage points. ROE is net income over average total equity in percentage points. Risk-based capital ratio is defined as total regulatory capital as a percentage of riskadjusted assets. Tier 1 capital ratio is core capital (Tier 1) as a percent of risk-adjusted assets. Abnormal accruals are abnormal loss provisions and are computed following Beatty, Ke and Petroni (2002). All the regressions include year and bank fixed effects. Standard errors, in parentheses, are clustered at the bank level. $* * *, * *$, and $*$ indicate statistically different from zero at the $1 \%, 5 \%$, and $10 \%$ level of significance, respectively.

Panel A. Full Sample

\begin{tabular}{lcccccc}
\hline \multirow{2}{*}{ Dependent Variable: } & NPLs/Loans & ROA & ROE & $\begin{array}{c}\text { Risk-Based } \\
\text { C.R. }\end{array}$ & Tier 1 C.R. & $\begin{array}{c}\text { Abnormal } \\
\text { Accruals }\end{array}$ \\
\cline { 2 - 7 } & $(1)$ & $(2)$ & $(3)$ & $(4)$ & $(5)$ & $(6)$ \\
\hline Post $\times$ Treated & $-3.708^{* * *}$ & $1.418^{* * *}$ & $15.390^{* * *}$ & 0.344 & -0.088 & $-0.605^{* * *}$ \\
Post & $(0.602)$ & $(0.290)$ & $(4.030)$ & $(0.584)$ & $(0.705)$ & $(0.171)$ \\
& 0.901 & -0.123 & -0.031 & $-1.065^{* *}$ & -0.558 & -0.046 \\
Observations & $(0.564)$ & $(0.328)$ & $(4.192)$ & $(0.432)$ & $(0.450)$ & $(0.208)$ \\
$\mathrm{R}^{2}$ & 595 & 593 & 591 & 595 & 595 & 579 \\
\hline Year FE & 0.744 & 0.452 & 0.428 & 0.661 & 0.663 & 0.483 \\
Firm FE & $\mathrm{X}$ & $\mathrm{X}$ & $\mathrm{X}$ & $\mathrm{X}$ & $\mathrm{X}$ & $\mathrm{X}$ \\
& $\mathrm{X}$ & $\mathrm{X}$ & $\mathrm{X}$ & $\mathrm{X}$ & $\mathrm{X}$ & $\mathrm{X}$ \\
\hline \multirow{2}{*}{ Dependent Variable: } & $\mathrm{NPLs} /$ Loans & $\mathrm{ROA}$ & $\mathrm{ROE}$ & $\mathrm{Risk}-\mathrm{Based}$ & Tier 1 C.R. & Abnormal \\
\cline { 2 - 7 } & $(1)$ & $(2)$ & $(3)$ & $(4)$ & $(5)$ & $(6)$ \\
\hline Post $\times$ Treated & $-2.288^{*}$ & $1.198^{* *}$ & $17.934^{* *}$ & -0.326 & -0.573 & $-0.465^{* *}$ \\
Post & $(1.274)$ & $(0.463)$ & $(7.184)$ & $(1.601)$ & $(1.664)$ & $(0.194)$ \\
& 0.630 & 0.799 & 8.683 & 1.840 & $2.521^{*}$ & $-0.462^{*}$ \\
Observations & $(2.254)$ & $(0.612)$ & $(8.947)$ & $(1.293)$ & $(1.256)$ & $(0.255)$ \\
$\mathrm{R}^{2}$ & 211 & 211 & 211 & 211 & 211 & 193 \\
\hline Year FE & 0.626 & 0.465 & 0.416 & 0.599 & 0.637 & 0.426 \\
Firm FE & $\mathrm{X}$ & $\mathrm{X}$ & $\mathrm{X}$ & $\mathrm{X}$ & $\mathrm{X}$ & $\mathrm{X}$ \\
\hline & $\mathrm{X}$ & $\mathrm{X}$ & $\mathrm{X}$ & $\mathrm{X}$ & $\mathrm{X}$ & $\mathrm{X}$ \\
\hline
\end{tabular}




\section{Appendix A5 Stock Market Reaction to Treasury Director Ap- pointments}

Figure A5

Long-Run Returns

Figure A5 plots buy-and-hold 1, 2,...,12-month net returns (i.e., net of the risk-free rate) for treated and control banks, where "treated" are banks receiving a board appointment.

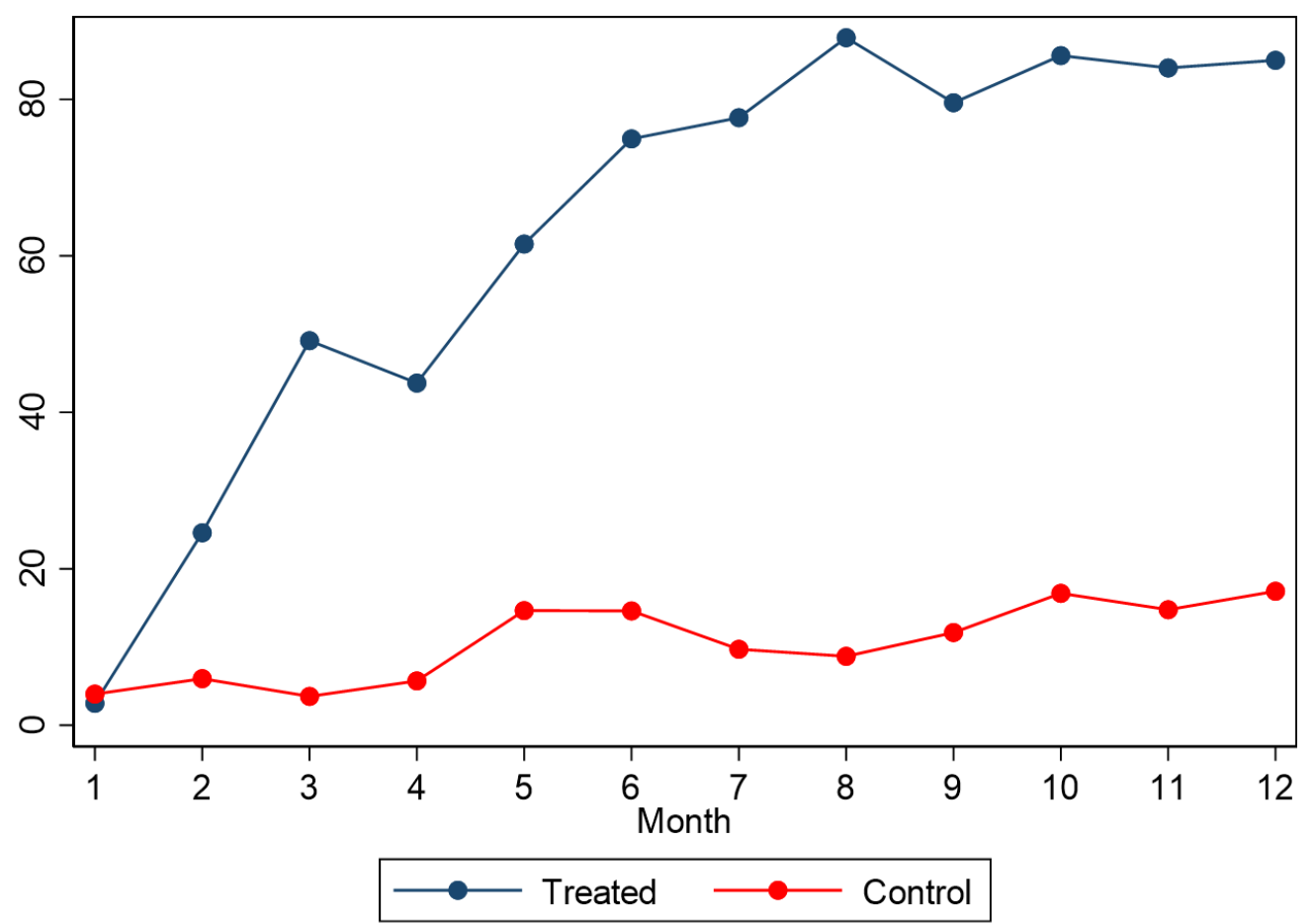




\section{Table A5}

\section{Stock Market Response: Short and Long Run}

Table A5 presents regressions where the dependent variables are stock returns at different horizons. In columns 1 through 4, the dependent variable is the cumulative abnormal return over a three-day window surrounding the announcement of the appointment of a director by the Treasury through an 8-K filing. In columns 5 through 8 , the dependent variable is the 12-month buy-and-hold return, measured starting from the month following the appointment. In columns $1,3,5$, and 7 , stock returns are adjusted using the market model. When indicated, control variables include the logarithm of market capitalization, the book to market ratio, and the lagged 12-month buy-and-hold return. All the regressions include match fixed effects. Heteroscedasticity-consistent standard errors are reported in parentheses. $* * *, * *$, and $*$ indicate statistically different from zero at the $1 \%, 5 \%$, and $10 \%$ level of significance, respectively.

\begin{tabular}{|c|c|c|c|c|c|c|c|c|}
\hline \multirow{2}{*}{ Window: } & \multicolumn{4}{|c|}{$($ Day -1, Day +1) } & \multicolumn{4}{|c|}{$($ Month +1 , Month +12$)$} \\
\hline & $(1)$ & $(2)$ & $(3)$ & $(4)$ & $(5)$ & $(6)$ & $(7)$ & $(8)$ \\
\hline Treated & $\begin{array}{c}1.238 \\
(1.705)\end{array}$ & $\begin{array}{c}1.842 \\
(1.837)\end{array}$ & $\begin{array}{l}1.709 \\
(2.630)\end{array}$ & $\begin{array}{c}1.532 \\
(2.480)\end{array}$ & $\begin{array}{l}52.204^{* *} \\
(14.204)\end{array}$ & $\begin{array}{c}* * 57.990 * * \\
(14.096)\end{array}$ & $\begin{array}{c}k * 52.356 * * \\
(15.777)\end{array}$ & $\begin{array}{l}54.100^{* *} \\
(17.692)\end{array}$ \\
\hline Log(Capitalization) & & & $\begin{array}{l}-0.107 \\
(0.430)\end{array}$ & $\begin{array}{c}0.173 \\
(0.548)\end{array}$ & & & $\begin{array}{l}-3.099 \\
(2.800)\end{array}$ & $\begin{array}{l}-2.625 \\
(3.448)\end{array}$ \\
\hline Book to Market & & & $\begin{array}{l}-0.008 \\
(0.010)\end{array}$ & $\begin{array}{c}0.013 \\
(0.012)\end{array}$ & & & $\begin{array}{l}-0.263^{* *} \\
(0.110)\end{array}$ & $\begin{array}{l}-0.180 \\
(0.140)\end{array}$ \\
\hline $\operatorname{Return}_{t-12, t-1}$ & & & $\begin{array}{c}0.016 \\
(0.033)\end{array}$ & $\begin{array}{l}-0.004 \\
(0.036)\end{array}$ & & & $\begin{array}{l}-0.246 \\
(0.276)\end{array}$ & $\begin{array}{c}-0.313 \\
(0.293)\end{array}$ \\
\hline Observations & 18 & 18 & 18 & 18 & 21 & 21 & 20 & 20 \\
\hline $\mathrm{R}^{2}$ & 0.682 & 0.751 & 0.697 & 0.762 & 0.906 & 0.918 & 0.937 & 0.938 \\
\hline Match FE & $\mathrm{X}$ & $\mathrm{X}$ & $\mathrm{X}$ & $\mathrm{X}$ & $\mathrm{X}$ & $\mathrm{X}$ & $\mathrm{X}$ & $\mathrm{X}$ \\
\hline Return Adjustment & MM & $\mathrm{FF}$ & MM & $\mathrm{FF}$ & MM & $\mathrm{FF}$ & MM & $\mathrm{FF}$ \\
\hline
\end{tabular}




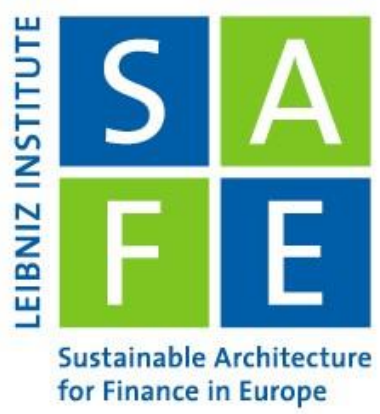

\section{Recent Issues}

No. 315 Kevin Bauer, Moritz von Zahn, Oliver Hinz

No. 314 Farshid Abdi, Mila Getmansky Sherman, Emily Kormanyos, Loriana Pelizzon, Zorka Simon

No. 313 Kevin Bauer, Andrej Gill

No. 312 Can Gao lan Martin

No. 311 Wenhui Li, Christian Wilde

No. 310 Carmelo Latino, Loriana Pelizzon, Aleksandra Rzeźnik

No. 309 Tabea Bucher-Koenen, Andreas Hackethal, Johannes Koenen, Christine Laudenbach

No. 308 Thomas Pauls

No. 307 Ester Faia, Andreas Fuster, Vincenzo Pezone, Basit Zafar

No. 306 Aljoscha Janssen, Johannes Kasinger

No. 305 Sabine Bernard, Benjamin Loos, Martin Weber

No. 304 Monica Billio, Andrew W. Lo, Loriana Pelizzon, Mila Getmansky Sherman, Abalfazl Zareei

No. 303 Ankit Kalda, Benjamin Loos, Alessandro Previtero, Andreas Hackethal

No. 302 Tim A. Kroencke, Maik Schmeling, Andreas Schrimpf
Expl(Al)ned: The Impact of Explainable Artificial Intelligence on Cognitive Processes

A Modern Take on Market Efficiency: The Impact of Trump's Tweets on Financial Markets

Mirror, Mirror on the Wall:

Machine Predictions and Self-Fulfilling Prophecies

Volatility, Valuation Ratios, and Bubbles: An Empirical Measure of Market Sentiment

Separating the Effects of Beliefs and Attitudes on Pricing under Ambiguity

The Power of ESG Ratings on Stock Markets

Gender Differences in Financial Advice

The Impact of Temporal Framing on the Marginal Propensity to Consume

Biases in Information Selection and Processing: Survey Evidence from the Pandemic

Obfuscation and Rational Inattention in Digitalized Markets

The Disposition Effect in Boom and Bust Markets

Global Realignment in Financial Market Dynamics: Evidence from ETF Networks

Smart (Phone) Investing?

A Within Investor-Time Analysis of New Technologies and Trading Behavior

The FOMC Risk Shift 